\title{
ANÁLISE DA QUALIDADE DO SOLO E AS ALTERAÇÕES SOCIOAMBIENTAIS OCORRIDAS À MARGEM DIREITA DO RIO ITACAIÚNAS, APÓS A DUPLICAÇÃO DA PONTE DE CONCRETO NA BR- 230, MARABÁ-PA
}

\author{
Milena Cristina Dias Barros e Antônio Pereira Júnior \\ DOI: $10.4322 / 978-85-455202-1-4-05$ \\ INTRODUÇÃO
}

\begin{abstract}
Os ecossistemas terrestres têm como base de sustentação o solo, que, além de servir de suporte para as raízes, desempenha funções essenciais para a funcionalidade e sustentabilidade dos mesmos. Por isso, o bom funcionamento deste recurso é essencial para os processos vitais à manutenção do planeta, como a reciclagem de elementos químicos, a regulação do fluxo hídrico e de energia, o armazenamento de carbono e emissão de gases e a manutenção e diversidade da fauna e flora (SIQUEIRA et al., 2008).

O solo possui as funções de armazenar e purificar a água, promover a biodegradação de poluentes, restaurar e aumentar a resiliência dos ecossistemas e promover a ciclagem de elementos químicos como carbono, nutrientes e metais pesados. Pela fundamental importância deste recurso natural, aumenta-se cada vez mais o interesse em estudos sobre a qualidade do solo (QS), considerada como um requisito fundamental para o equilíbrio e manutenção dos ecossistemas, já que suas implicações não se restringem somente ao ambiente solo, mas se estendem à hidrosfera, atmosfera e biosfera, atuando na qualidade da água, do ar e na biodiversidade (VEZZANI et al., 2008).

Considera-se a qualidade do solo como o grau em que o mesmo pode: (I) promover atividade biológica (plantas, animais e microorganismos); (II) mediar o fluxo de água; (III) manter a qualidade do ambiente, agindo como um tampão e assimilando resíduos orgânicos e outros. Ou seja, é a capacidade do solo de exercer suas funções na natureza para sustentar a produtividade biológica, manter a qualidade ambiental e promover a saúde das plantas e animais (AQUINO, 2005; ARAÚJO, 2005).
\end{abstract}

A avaliação da qualidade do solo é realizada por intermédio da mensuração de indicadores, que, em geral medem a perturbação do ambiente através de alterações na diversidade, abundância e composição de seus grupos. Tais indicadores são classificados geralmente em: físicos (textura, o tipo de argila, a profundidade do substrato e a classe de drenagem), químicos ( $\mathrm{pH}$, matéria orgânica, capacidade de troca de cátions) e biológicos (a massa microbiológica, o nível de respiração do solo e, principalmente a diversidade da fauna edáfica) (ARAÚJO, et al., 2012; CARVALHO et al., 2007; PEREIRA JÚNIOR, 2011; VICENTE et al., 2010).

Mesmo sendo clara a importância do solo na manutenção dos ecossistemas, o uso intensivo e inadequado das diversas áreas exploradas tem contribuído para o declínio considerável da fertilidade natural deste recurso. Esse manejo inadequado tem contribuído para o processo de degradação da matéria orgânica, causando perdas de algumas propriedades físicas, químicas e biológicas, acelerando a erosão e diminuindo o potencial produtivo (CORDEIRO et al., 2004).

No município de Marabá, sudeste do Estado do Pará, esta realidade não é diferente de outros municípios, pois ele tem apresentado um acentuado índice de crescimento urbano motivado tanto pela localização geográfica estratégica, quanto pela dinâmica de relações econômicas que configuram as atividades de extrativismo, da agropecuária, da indústria e comércio da região (DNIT, PCA, 2009).

Este crescimento gerou a necessidade de manter, ao longo dos anos, investimentos intensos em infraestrutura urbana. Dentro deste grupo encontra-se a duplicação da Rodovia Transamazônica 
(BR-230), incluindo a duplicação da ponte Rio Itacaiúnas, objeto deste estudo, que, como toda atividade antrópica, deve ter provocado alterações no ambiente em que foi inserida.

Neste contexto objetivou-se a avaliação e discussão da qualidade do solo após a obra de infraestrutura da duplicação da ponte sobre o Rio Itacaiúnas, no município de Marabá, Pará, principalmente sobre à instalação das unidades de apoio à obra, utilizando a fauna edáfica coletada na área como indicadora da qualidade do solo e das alterações nele ocorridas.

\section{REFERENCIAL TEÓRICO}

\section{COMUNIDADE VILA SOCÓ - HISTÓRICO}

A pequena comunidade da Vila Socó localizava-se no município de Marabá, entre os núcleos Marabá Pioneira e Cidade Nova, às margens do rio Itacaiúnas e da Rodovia Transamazônica, mas especificamente na margem direita do rio e a jusante da ponte do Rio Itacaiúnas (RIBEIRO, 2009a). O vilarejo existia a mais de 30 anos, e abrigava aproximadamente 107 famílias de baixa renda (Figura 1a), que ocupavam casas de madeira em geral (Figura 1b).

Figura 1 - a) Vista frontal da Vila Socó; b) os barracos de madeira. Vila Socó. Marabá PA.

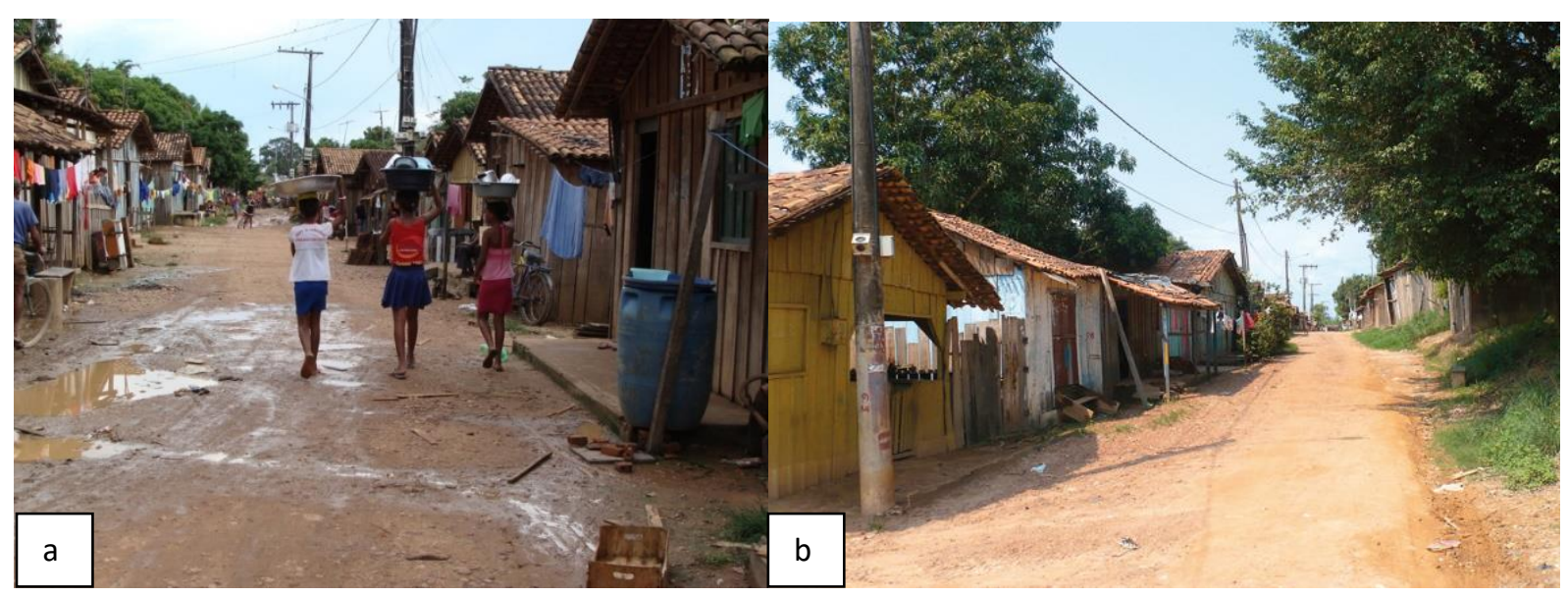

Fonte: Jornal Opinião (2009).

Economicamente, a principal atividade da comunidade era a olaria artesanal, a qual se limitava ao período de estiagem, pois, quando começam as chuvas e, especialmente com o aumento do nível do rio, geralmente entre os meses de novembro a abril, a atividade ficava paralisada, então as pessoas tentavam sobreviver da pesca que mal dava para suprir a alimentação. A olaria rendia cerca de $\mathrm{R} \$$ 400,00 por mês às famílias que não recebiam nenhum tipo de benefício social e nem ajuda por parte de entidades civis e religiosas (SOUSA, S., 2009).

De acordo com notícias de jornais e revistas do período (O Liberal, Correio do Tocantins, Opinião, Revista Foco Carajás) do auge da problemática de desapropriação para a obra de duplicação da ponte do Rio Itacaiúnas (dos anos de 2009 e 2010), a maior queixa dos moradores era da falta de políticas públicas na comunidade. Além disso, nenhuma rua do vilarejo tinha asfalto ou saneamento, muito menos água encanada.

$\mathrm{Na}$ pequena vila havia uma escola que atendia crianças até a segunda série do Ensino Fundamental. Já os demais alunos precisavam deslocar-se até os bairros vizinhos, que não ficavam tão próximos assim. A escola contava com um poço do qual a comunidade retirava água para tarefas domésticas de higiene e limpeza. No entanto, para beber e cozinhar, eles eram obrigados a buscar o líquido na Marabá Pioneira (RIBEIRO, 2009b). 
Outra dificuldade na vila era quanto ao transporte urbano, pois os pontos de ônibus mais próximos ficavam na entrada da Marabá Pioneira ou após a ponte do Rio Itacaiúnas. Além dessa desvantagem, os moradores cujas casas ficavam ao lado da rodovia temiam por um desabamento do barranco ou que algum carro saísse da pista e caísse sobre as residências (SOUSA, E., 2009).

Devido à obra de duplicação da ponte sobre o rio Itacaiúnas, realizada com recursos da União, a chamada Vila Socó, teve de ser desativada para dar lugar à grande obra de infraestrutura (Figura 2a). Na época houve resistência, e muita polêmica em torno do remanejamento dessas famílias (Figura 2b) que alegavam não ter outro local onde pudessem desenvolver suas atividades. De acordo com o Plano de Controle Ambiental da obra (DNIT, 2009) as famílias começaram a ser deslocadas involuntariamente em 2009.

Figura 2 - a) Infraestrutura do empreendimento; b) Remoção das famílias residentes na área do empreendimento.

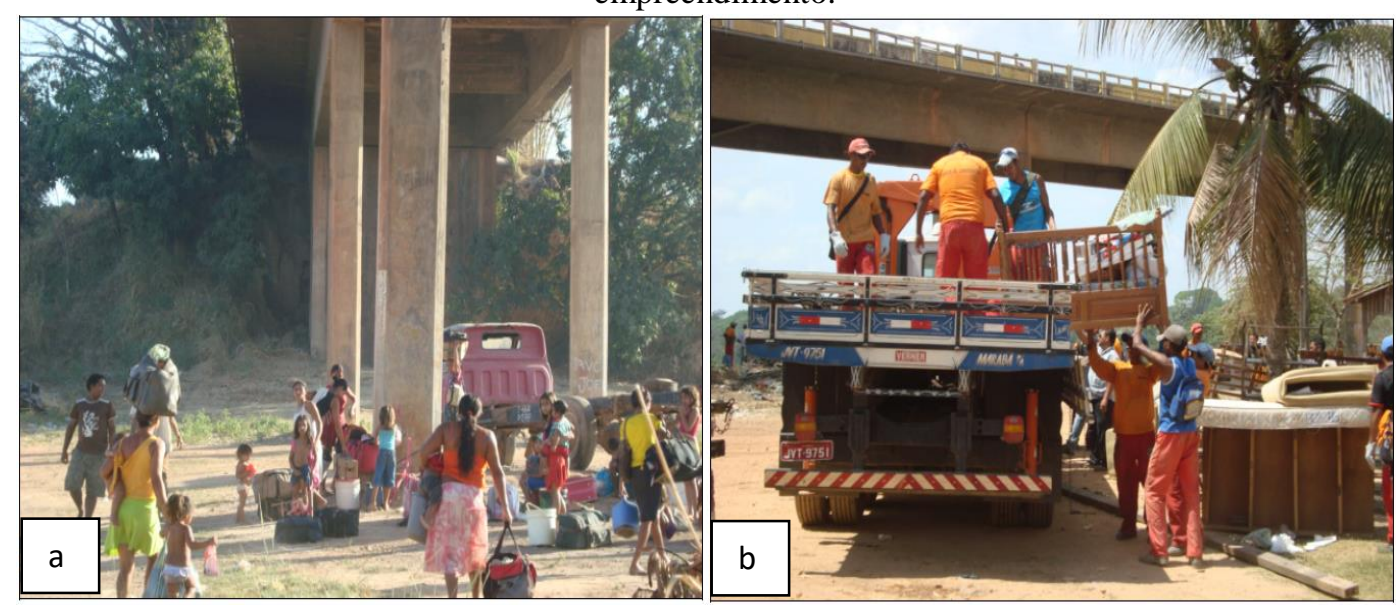

Fonte: DNIT (2009).

A remoção das famílias residentes na extinta Vila Socó foi uma grande problemática que durou muitos meses e envolveu o Ministério Público. No início, as famílias queriam indenização além de serem deslocadas para outros locais, no entanto, a prefeitura afirmava não ter condições financeiras de realizar tal pagamento.

Em outra ocasião, a prefeitura tentou um acordo para que as famílias fossem transferidas para casas alugadas, até a construção de novas habitações na época. De acordo com uma reportagem do Jornal Opinião, publicada em 14 de abril de 2009, houve a celebração de um acordo intermediado pelo Ministério Público, onde foi acordado que a prefeitura do município de Marabá iria indenizar as casas pelo valor de $\mathrm{R} \$ 25.000,00$ (vinte e cinco mil reais) cada uma, além da compra de equipamentos para a que a produção de telhas e tijolos fosse feita de forma industrializada, e não mais artesanal, que provavelmente passaria a ser desenvolvida em outro local predeterminado. $\mathrm{O}$ equipamento ficou avaliado em $\mathrm{R}$ \$ 1.050,00 milhão. Além disso, a prefeitura assumiu o compromisso quanto a aquisição da produção total dos oleiros (SANTOS, 2009).

O Plano de Controle Ambiental da obra (DNIT, 2009), afirma que parte os moradores da vila foram remanejados para casas construídas pela Prefeitura Municipal (Figura 3), no entanto este mesmo documento não informa a localidade dessas construções. 
Figura 3 - Casas construídas pela Prefeitura de Marabá - PA.

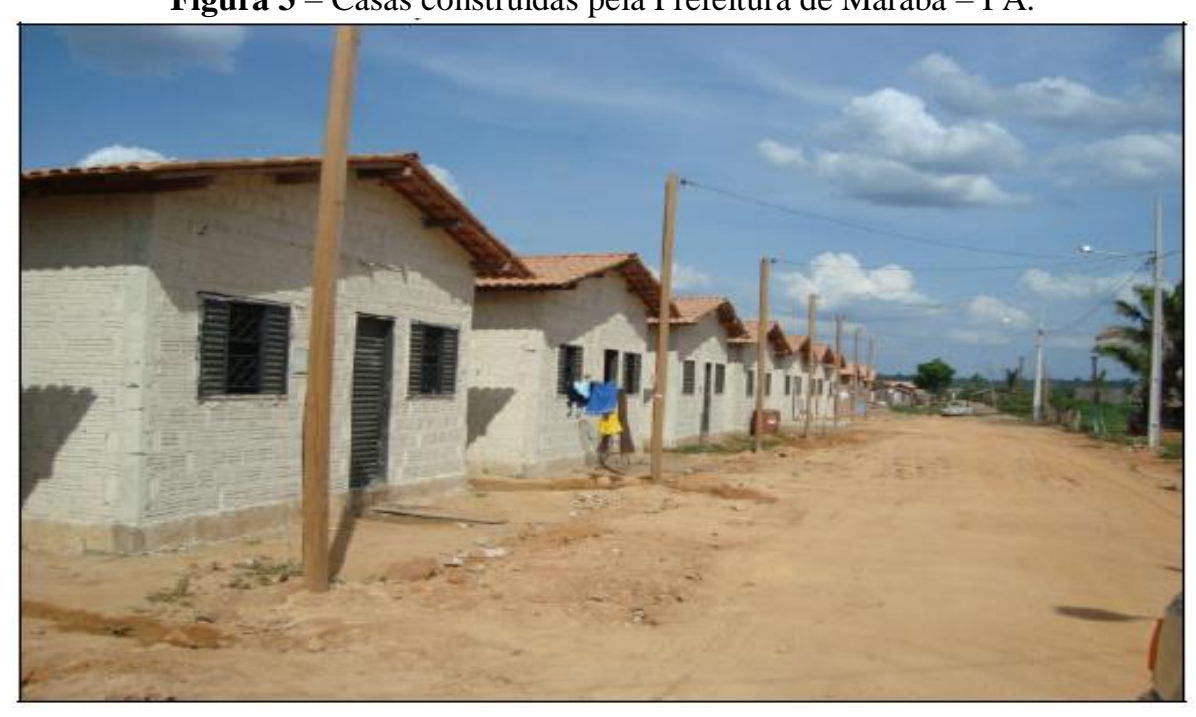

Fonte: DNIT (2009).

As informações mais recentes sobre esta situação, obtidas no jornal local Opinião, afirmam que os oleiros remanejados da antiga Vila Socó, desmotivados pela espera no cumprimento do acordo celebrado entre a comunidade e a Prefeitura Municipal com interveniência do Ministério Público Estadual (MPE), pretendiam uma nova situação. No lugar da verba para os maquinários que seriam usados na industrialização da argila, os "profissionais do barro" queriam a criação de um Parque Ambiental Municipal (PAM) a ser implantado na mesma área da antiga olaria, no aterro que dá acesso para a Marabá Pioneira.

Ainda de acordo com essa reportagem o Parque Ambiental seria criado pela Companhia Vale do Rio Doce (VALE), como já ocorreu em Paragominas e Parauapebas, e teria como meta principal a revitalização da área da antiga olaria, seriamente prejudicada pelos vários anos da exploração indiscriminada da argila, para a produção de telhas e tijolos de forma artesanal. A ideia é desenvolver atividades de preservação de espécies ameaçadas de extinção como tracajás, sucuris, antas, jacarés, capivaras, pássaros que têm naquele local seu habitat natural, entre outros animais.

O Senhor Edson Feitosa, presidente do Fundo Florestal da Amazônia, uma Organização Não Governamental (ONG) criada especificamente para defender os direitos dos oleiros, informou à redação do Jornal OPINIÃO que o projeto já foi aprovado pelo Instituto Brasileiro de Meio Ambiente e Recursos Naturais Renováveis (IBAMA) e conta com o apoio do biólogo Noé Von Natizingen, presidente da Fundação Casa da Cultura, instituição bastante conceituada e de influência no município. Até o momento a criação deste Parque Ambiental não foi decretada, no entanto, o projeto já coletou mais de 1000 (mil) assinaturas e ainda está sujeito à aprovação pelos órgãos públicos responsáveis, a Secretaria Municipal de Meio Ambiente e a Câmara de Vereadores, por exemplo.

\section{QUALIDADE DO SOLO}

A grande maioria dos estudos já realizados sobre qualidade do solo (ARAÚJO et al., 2007; CASALINHO, 2007; CONCEIÇÃO et al., 2005; D' ANDRÉA et al., 2002; FERREIRA, 2005; MERLIM, 2005) admitem que não existe consenso com relação ao conceito deste tema devido suas múltiplas definições, no entanto é unânime que todos os estudos relevantes destacam o conceito da QS para Doran, Parkin (1994):

Como a capacidade que um determinado tipo de solo apresenta, em ecossistemas naturais ou agrícolas, para desempenhar uma ou mais funções relacionadas à sustentação da atividade, da produtividade e da diversidade biológica, à manutenção da qualidade do ambiente, à promoção da saúde das plantas e dos animais e à sustentação de estruturas socioeconômicas 
e de habitação humana (ARAÚJO et al., 2007; CASALINHO, 2007; CONCEIÇÃO et al., 2005; D’ ANDRÉA et al., 2002; FERREIRA, 2005; MERLIM, 2005; VEZZANI, et al., 2008).

Outras definições para a qualidade do solo: (I) capacidade de funcionar como ecossistema natural ou manejado para sustentar a produtividade animal e vegetal, manter a qualidade da água e do ar e suportar o crescimento humano; (II) a capacidade do solo de funcionar dentro dos limites do ecossistema e interagir positivamente com o meio ambiente externo daquele ecossistema; (III) capacidade do solo de sustentar a diversidade biológica, regular o fluxo de água e solutos, degradar e imobilizar compostos orgânicos e inorgânicos e atuar na ciclagem de nutrientes e outros elementos (NEVES JÚNIOR, 2008; OLIVEIRA, 2013; PEREIRA JÚNIOR, 2011; VEZZANI; MIELNICZUK, 2009).

O interesse no estudo sobre a qualidade do solo (QS) aumentou consideravelmente na década de 90, época em que também surgiu seu conceito nas literaturas especializadas. A qualidade do solo é definida como a capacidade deste de funcionar dentro do ecossistema para sustentar a produtividade biológica, manter a qualidade ambiental e promover a saúde das plantas e animais (ARAÚJO, 2005).

Um determinado tipo de solo pode ser considerado com boa qualidade quando apresentar a capacidade, dentro dos limites de um ecossistema natural ou manejado, de manter a produtividade e a biodiversidade vegetal e animal, melhorar a qualidade do ar e da água e contribuir para a habitação e a saúde humana (CASALINHO, 2007).

No que diz respeito à avaliação da qualidade do solo, ainda não existe um método prático e confiável para estimar a qualidade do solo, porém, mudanças na QS têm sido avaliadas por intermédio da mensuração de indicadores apropriados e pela sua comparação com valores desejáveis (limite crítico) em diferentes intervalos de tempo, para um fim específico em ecossistemas agrícolas, florestais e pecuários (ARAÚJO et al., 2012).

\section{INDICADORES DA QUALIDADE DO SOLO}

Indicadores da qualidade do solo podem ser classificados, em três grupos: físicos, químicos e biológicos (BERTINI, 2010; CONCEIÇÃ̃O, 2005; VEZZANI; MIELNICZUK, 2009). Pode-se ainda acrescentar mais um grupo a esses três tipos: os indicadores visuais. São aqueles obtidos a partir de observações ou interpretação de fotografias aéreas, ou através de observações diretas. Mudanças na cor do solo, acúmulo de água e enxurradas são exemplos desse grupo, e, indicam claramente se a qualidade do solo está ameaçada ou passando por alterações (SANTANA; BAHIA FILHO, 1999).

A identificação dos indicadores para a qualidade do solo (QS) apresenta grande importância porque essa qualidade é fortemente influenciada pelos processos mediados por indicadores biológicos, físicos e químicos que promovem: ciclagem de nutrientes, capacidade nutricional, estabilidade aos agregados do solo, fatores estes que proporcionam a sustentação da produtividade e a promoção da saúde vegetal e ambiental (ARAÚJO et al., 2007; CASALINHO 2007; VEZZANI; MIELNICZUK, 2009).

Atualmente, há uma tendência de agrupar os indicadores físicos, químicos e biológicos para gerar um indicador geral da qualidade do solo (General Indicator of Soil Quality - GISQ). Os cinco subindicadores que embasam o GISQ são: composição da macrofauna do solo; propriedades físicas do solo; fertilidade química do solo; morfologia do solo e estado dos níveis orgânicos do solo. O uso dessa metodologia indica que, quanto melhor for à qualidade do solo, mais serviços por ele serão prestados ao ecossistema (PEREIRA JUNIOR, 2011).

\section{FÍSICOS}

A análise física e a descrição de caracteres morfológicos do solo possuem elevada importância para a avaliação do solo e definição do manejo a ser adotado, sendo, bastante recomendável para 
avaliar e entender o complexo de fatores que cercam o vegetal no interior do solo. Do ponto de vista das atividades agrícolas, os indicadores físicos estabelecem relações fundamentais com os processos hidrológicos, como taxa de infiltração, escoamento superficial, drenagem e erosão. Possuem também função essencial no suprimento e armazenamento de água, de nutrientes e de oxigênio no solo (GOMES; FILIZOLA, 2006).

Os indicadores físicos estão relacionados ao arranjo das partículas e do espaço poroso do solo. Inclui densidade, textura, o tipo de argila, a profundidade do substrato, resistência à penetração, espessura, profundidade de enraizamento, compactação, condutividade hidráulica e a classe de drenagem (OLIVEIRA, 2013; VEZZANI; MIELNICZUK, 2009). Para efeito deste trabalho será dada ênfase à classificação textural.

A granulometria relaciona a proporção existente em relação ao tamanho da partícula da fração ativa, permitindo obter a classe textural do solo. Para efeitos de classificação relaciona-se o solo pelos diferentes diâmetros de suas partículas: quanto à fração grosseira (matacão, calhau e cascalho) e, fração fina (areia grossa, areia fina, silte e argila). Nos solos que predominam frações menores em relação à fração grosseira, distinguem-se apenas três frações: areias, silte e argila (SILVA, 2003).

Ainda de acordo com este autor as diversas proporções entre estes três componentes anteriormente citados influenciam marcadamente na retenção de água e nutrientes e, originam a classificação textural, que é obtida através das percentagens de areia, silte e argila. Exemplos dessas classes são: franco argiloso, franco arenoso, argilo arenoso, franco siltoso, franco argilo siltoso, argilo arenoso, dentre outros.

De maneira geral solos arenosos possuem uma baixa capacidade de retenção de água e podem ser prejudiciais ao crescimento das plantas, devido a sua baixa capacidade de retenção de cátions $\left(\mathrm{Ca}^{2+}, \mathrm{Mg}^{2+}, \mathrm{K}^{+}\right.$e $\left.\mathrm{Na}^{+}\right)$, que são facilmente perdidos por lixiviação, resultando em um solo estéril. Já os solos argilosos apresentam maior capacidade de retenção catiônica, porque o conteúdo de argila é positivamente correlacionado com a matéria orgânica e, porque a fração argila também retém os cátions, independentemente de seu conteúdo de matéria orgânica (FEARNSIDE; LEAL FILHO, 2001).

\section{QUÍMICOS}

$\mathrm{O}$ pH, salinidade, capacidade de troca de cátions, matéria orgânica, concentrações de elementos que podem ser potencialmente contaminantes (metais pesados, compostos radioativos, etc.) são considerados indicadores químicos. As condições químicas do solo afetam as relações soloplanta, a qualidade da água, o poder tampão, a disponibilidade de nutrientes e de água para as plantas e outros organismos (ARAÚJO et al., 2012). Dentre os indicadores químicos citados anteriormente, e os que estão envolvidos com a fertilidade do solo destacam-se:

1. Potencial hidrogeniônico $(\mathrm{pH})$ : é afetado por fatores como clima, vegetação e material de origem do solo. Há predominância de alumínio, que é solúvel em meio ácido e, em reação com a água (hidrólise), produz cátions H+ (BASTOS, 2008; KIEHL, 1979; PEREIRA JÚNIOR, 2011). A Amazônia apresenta solos ácidos com pH entre 4 e 6,5, mas esta faixa se difere da que atualmente é considerada adequada para o desenvolvimento de diversas culturas cultivadas na Amazônia, sendo esta entre 5,5 e 6,5. Promove-se nessa faixa disponibilidade de macronutrientes e de micronutrientes, como o ferro, cobre manganês e zinco, que são menos exigidos pelos vegetais e estão presentes nesta faixa sugerida (SILVA, 2003; SILVA et al., 2006).

2. Matéria orgânica (MO): refere-se a todo material orgânico contido no solo, incluindo a serrapilheira, a biomassa microbiana, substâncias orgânicas solúveis em água e a matéria orgânica estabilizada, ou seja, os húmus (CASTRO, 2008; LONGO; ESPÍNDOLA, 2000). Exerce um papel importante no solo, pois sua presença propicia a melhoria da estrutura e aeração (solo friável e poroso), e é responsável também pelo aumento da retenção de umidade. Também participa ativamente na reação da capacidade de troca catiônica, pois quanto maior o teor de MO e de argila, maior será a 
reação da CTC o que favorece a fertilidade do solo porque poderá ocorrer maior absorção de nutrientes catiônicos pelas plantas. (ARAÚJO et al., 2012; BELIZÁRIO, 2008).

O carbono orgânico é o elemento fundamental na determinação da relação $\mathrm{C} / \mathrm{N}$, a qual informa o estado de decomposição da matéria orgânica decorrente da ação microbiana. Assim, relações de baixo valor (em torno de 10) indicam avançado estágio de decomposição de $\mathrm{MO}$, e valores altos (em torno de 30) indicam baixa atividades microbianas (MACHADO, 2001). Em condições normais o valor desta relação situa-se entre oito e 14 (PEIXOTO, 2008; SILVA, 2003).

3. A Capacidade de Troca de Cátions (CTC): como, por exemplo, $\mathrm{K}^{+1}, \mathrm{Ca}^{+2}, \mathrm{Mg}^{+2}$, $\mathrm{NH}_{4}{ }^{+1}, \mathrm{H}^{+1}$ e $\mathrm{Al}^{+3}$, é um mecanismo importante para retenção e fornecimento nutricional às plantas, além de atuar na adsorção de contaminantes. Em solos arenosos a capacidade de adsorção é baixa, devido à baixa reação da CTC, o que já não ocorre em solos argilosos. A CTC é de grande importância no que diz respeito à fertilidade do solo, uma vez que indica a capacidade total de retenção de cátions, os quais, em geral, irão tornar-se disponíveis às plantas (CARVALHO et al., 2007).

Além destes, existem os indicadores químicos ligados à necessidade nutricional $(\mathrm{Ca}, \mathrm{Mg}, \mathrm{Na}$, $\mathrm{N}, \mathrm{P}, \mathrm{K}$ ), podem ter seus valores alterados através do manejo inadequado do solo, o que pode comprometer a QS e consequentemente a manutenção da produção vegetal (PEREIRA JÚNIOR, 2011).

\section{BIOLÓGICOS}

Os indicadores biológicos, ao contrário dos físicos e químicos, apresentam alta capacidade para demonstrar mudanças na qualidade do solo porque os microrganismos respondem rapidamente a estas mudanças. Um dos indicadores biológicos da QS é a microbiota contida no solo (ARAÚJO et al., 2012). A atividade biológica é altamente concentrada nas primeiras camadas do solo, na profundidade entre 1 a $30 \mathrm{~cm}$. Nestas camadas, o componente biológico ocupa uma fração de menos que $0,5 \%$ do volume total do solo e representa menos que $10 \%$ da matéria orgânica. Este componente biológico consiste principalmente de microrganismos que realizam diversas funções essenciais para o funcionamento do solo (ARAÚJO; MONTEIRO, 2007).

Em síntese, os tipos de indicadores do solo quanto a sua origem física, química ou biológica (Tabela 1), permitem análises ambientais que determinam alterações ocorridas no solo, e assim, exercer a monitoração e avaliação da qualidade do solo.

Tabela 1 - Principais tipos de indicadores da qualidade do solo e suas relações com o mesmo.

\begin{tabular}{|c|c|}
\hline Indicadores & Relação com a qualidade do solo \\
\hline \multicolumn{2}{|l|}{ FÍSICOS } \\
\hline Estrutura do solo & Retenção de água e nutrientes. \\
\hline Infiltração e densidade aparente & Movimento de água e porosidade do solo. \\
\hline Capacidade de retenção de umidade & Armazenamento e disponibilidade de água. \\
\hline \multicolumn{2}{|l|}{ QUÍMICOS } \\
\hline $\mathrm{pH}$ & Atividade biológica e disponibilidade de nutrientes. \\
\hline Condutividade elétrica & Crescimento vegetal e atividade microbiana. \\
\hline Conteúdo de N, P e K. & Disponibilidade de nutrientes para as plantas. \\
\hline \multicolumn{2}{|l|}{ BIOLÓGICOS } \\
\hline Biomassa microbiana & Atividade microbiana e reposição de nutrientes. \\
\hline Mineralização de nutrientes (N, P e S) & $\begin{array}{l}\text { Produtividade do solo e potencial de suprimento de } \\
\text { nutrientes. }\end{array}$ \\
\hline Respiração do solo & Atividade microbiana. \\
\hline Fixação biológica do N2 (FBN) & Potencial de suprimento de $\mathrm{N}$ para as plantas. \\
\hline Atividade enzimática do solo & Atividade microbiana e catalítica no solo. \\
\hline
\end{tabular}

Fonte: Araújo e Monteiro (2007). 


\section{PEDOFAUNA}

Pedofauna ou Fauna do solo é o termo utilizado para referenciar à comunidade de invertebrados que vive permanentemente ou que passa um ou mais fases de desenvolvimento no solo, e uma da caraterísticas diferenciais entre eles, é o fato de que variam muito em tamanho, diâmetro e na sua capacidade de deslocamento. Isso permite adaptações a extensão em que sua a atividade ocorre, seja para alimentação e/ou escavação, ambas modificadoras das propriedades do solo, ciclagem dos nutrientes, e também a amplitude em que podem ser influenciados pelo manejo do solo (AQUINO, 2005; AQUINO; CORREIA, 2005; CORREIA; OLIVEIRA, 2006). De acordo com o tamanho e o local que ocupam no solo são classificados em micro, meso e macrofauna (Figura 4).

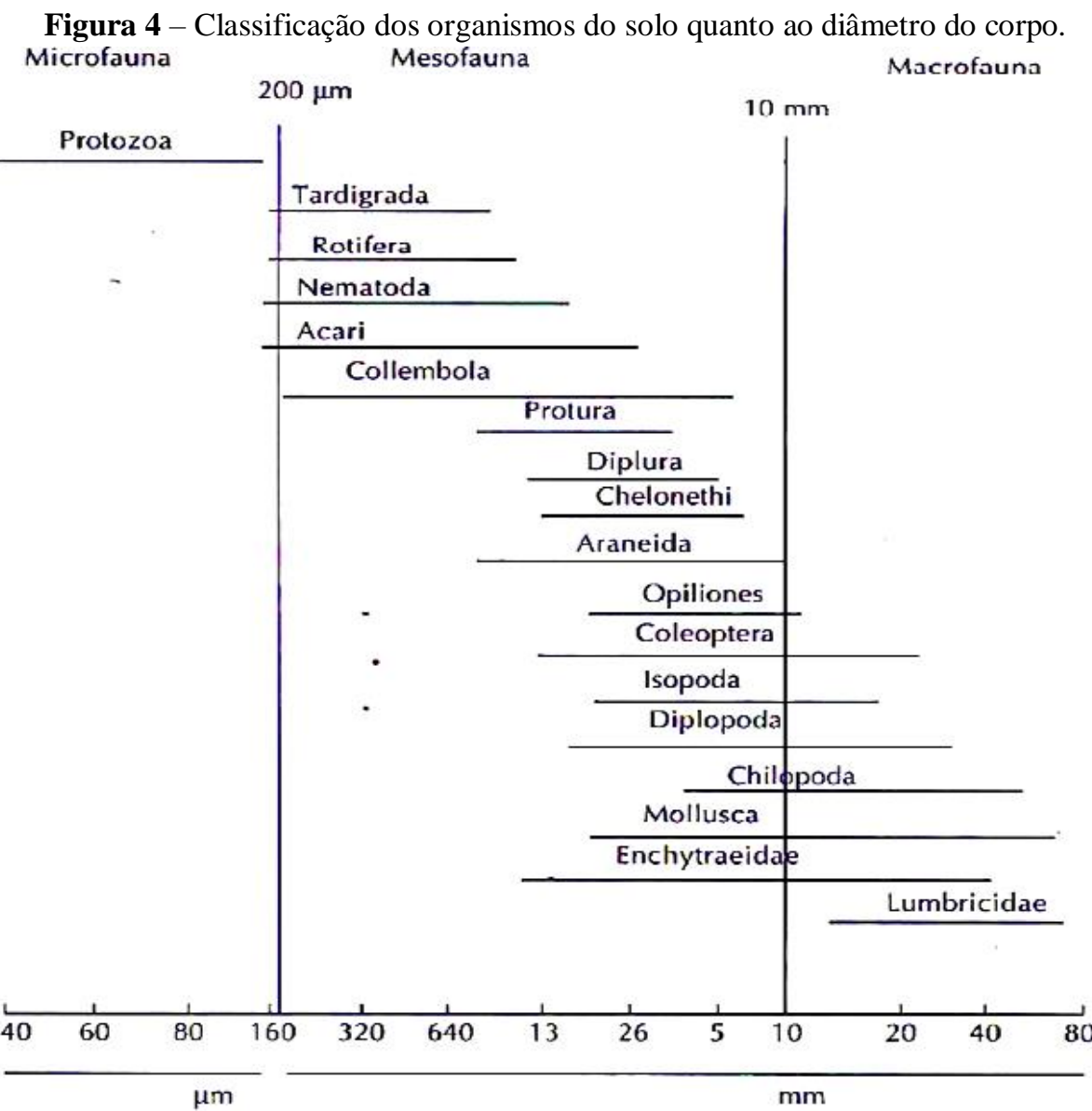

Fonte: Aquino e Correa (2005)

As minhocas são os principais representantes da macrofauna por serem importantes no ciclo de nutrientes, relacionadas à decomposição do material vegetal, e distribuição de nutrientes no solo, disponibilizando-os para a absorção pelas plantas. Outros animais da macrofauna como as térmitas (baratas, cupins) e as formigas são conhecidos como "engenheiros do solo" que, por se movimentarem no perfil do solo, modificam a estrutura do mesmo, e promovem a predação de outros invertebrados. Por isso também são considerados excelentes bioindicadores de distúrbios no ambiente (FREITAS, 2007; SILVA et al., 2006).

Dentro do grupo dos insetos, os mais importantes são as formigas, as térmitas, os coleópteros e os colêmbolos. Esses animais são responsáveis principalmente pelo transporte de grande quantidade 
de subsolo para a superfície (pela construção de seus ninhos), e também por serem agentes na fragmentação de material orgânico e sua mistura com o solo (DUCATTI, 2002).

Alguns macroinvertebrados podem ser relacionados com as indicações mais prováveis que justificam a presença desses organismos no solo e caracterizam-nos como indicadores da qualidade do mesmo (Tabela 2).

Tabela 2 - Alguns grupos de macroinvertebrados edáficos seus indicativos como indicadores de qualidade do solo.

\begin{tabular}{ll}
\hline \multicolumn{1}{c}{ Grupo de macroinvertebrados } & \multicolumn{1}{c}{ Tipo de indicação } \\
\hline Minhocas (Oligochaeta) & $\begin{array}{l}\text { Poluição do solo (pesticidas e metais pesados); } \\
\text { compactação; teor de matéria orgânica do solo e } \\
\text { condições hídricas do solo. }\end{array}$
\end{tabular}

Aranhas (Arachnida: Araneae), especialmente das famílias (Hahniidae, Liocranidae, Mysmenidae, Oonopidae e Theridiidae).

Isópodes (Isopoda)

Coleópteros (Coleóptera)

(Carabide Staphylinidae)

Diplópodes (Diplopoda)

Cupins (Isoptera)

Formigas (Hymenoptera)
Qualidade biológica de um hábitat; poluição do solo por metais pesados; evolução e estabilidade de diferentes biótipos e umidade do solo.

Poluição por metais pesados; presença de pesticidas no solo; simplificação da estrutura do habitat e perturbação mecânica do solo (estrutura do solo).

Fertilizantes (N, P e K) e pesticidas; indicadores do impacto de cultivos; perturbação da estrutura do solo; estrutura da paisagem; indicadores de umidade e poluição por metais pesados.

Umidade do hábitat, produtividade vegetal (biomassa) e biodisponibilidade de P2O5.

Indicador de áreas perturbadas (hábito sedentário); sensíveis indicadores da contaminação e da degradação ambiental (resposta à qualidade de recursos disponíveis).

Sistemas de culturas mais duráveis; modificação da paisagem; exploração industrial e a reabilitação do solo; qualidade e integridade do habitat; perturbações (queima) e mudanças no ambiente.

Fonte: Baretta (2007).

Além da classificação com base nas dimensões corporais, a fauna do solo pode, também, ser classificada com base em aspectos funcionais. A função dos invertebrados no solo depende principalmente de seus hábitos alimentares, de sua mobilidade e da posição que ocupam no espaço. A divisão dos grupos funcionais pode ser feita em saprófagos, micrófagos, predadores, insetos sociais e fitófagos. Com efeito, pelo hábito alimentar é possível avaliar as relações existentes entre os diferentes organismos e estimar sua influência nas características do solo (MOÇO, 2006).

A fauna do solo além de ser um agente é também um reflexo das condições do solo, pois a estrutura dos agregados, a quantidade de poros, umidade, teor de matéria orgânica, o teor de nutrientes, determinam quais os grupos de organismos estarão presentes em determinado solo e em qual quantidade. Desta forma mudanças na abundância relativa e na diversidade de espécies de organismos do solo constituem um bom indicador de mudanças no sistema (FREITAS, 2007; LOURENTE et al., 2007).

A captura da fauna edáfica é realizada normalmente pela técnica de coleta de armadilhas de interceptação e queda (Pitfall traps), que são recipientes enterrados no solo. Essas armadilhas são utilizadas para capturar os invertebrados tanto da meso, quanto da macrofauna que atuam na interface solo-serapilheira. Esse método pode dar uma indicação da atividade da fauna epígea, ou seja, dos 
componentes que atuam, principalmente na superfície do solo, tendo um caráter mais qualitativo que quantitativo (AQUINO; CORREIA, 2005; AQUINO et al., 2006b;).

Tudo o que foi afirmado demonstra a importância desses organismos na manutenção da ciclagem de nutrientes e na decomposição nos ecossistemas de modo a favorecer a incorporação da matéria orgânica. No entanto, esta fauna está sendo afetada por vários fatores, sejam naturais ou, principalmente antrópicos. No caso dos fatores naturais diz respeito às variações sazonais na estrutura das comunidades ou qualquer outra variação que implique na modificação da biodiversidade vegetal e o estado de decomposição dos resíduos vegetais (MACEDO, 2004).

Sobre os fatores antrópicos ressalta-se que de modo geral os organismos do solo são afetados, principalmente, por quatro mais frequentes: (1) Compactação e seus efeitos na porosidade, na circulação de água e de ar, e na mobilidade dos organismos no espaço poroso; (2) Profundidade de aração, que causa inversão de distribuição da fauna, o deslocamento de resíduos de plantas e mudanças nas condições de crescimento microbiano; (3) Diminuição da qualidade e da quantidade de material orgânico e redução no abrigo ou locais para oviposição, tendendo a reduzir a diversidade de espécies e a população total de organismos; (4) Destruição do revestimento vegetal do terreno, que causa flutuações microclimáticas e expõe os organismos aos excessos de temperatura do ar, pela exposição ao sol, a ciclos de umedecimento e secagem (estresse hídrico e inundação) e ao fogo (DUCATTI, 2002).

Todos esses fatores antrópicos irão implicar na perda da fauna do solo, no progressivo esgotamento do teor de matéria orgânica, deterioração estrutural do solo, esgotamento de nutrientes, redução na estabilidade da comunidade biológica, e, na diminuição da porosidade biológica do solo, ou seja, menor infiltração de água, maior erosão superficial, menor transferência de argila, maior acúmulo de areia residual, menor percolação de água, e, menor velocidade de formação dos solos (ANDRADE, 2000; CORREIA, 2002).

Por tudo isso não se tem mais dúvidas sobre à importância dos invertebrados como agentes transformadores das condições físicas químicas e biológicas do solo. A atividade alimentar destes organismos está intimamente associada aos processos de decomposição (através da fragmentação da serrapilheira), regulação de populações microbianas, ciclagem de nutrientes e a regulação dos processos biológicos, que são de fundamental importância para a manutenção da produtividade do ecossistema (CORREIA; OLIVEIRA, 2006).

\section{CANTEIRO DE OBRAS}

De acordo com a Norma Regulamentadora (NR) 18, canteiros de obras são áreas destinadas à execução e apoio dos trabalhos da indústria da construção, ou seja, são áreas de trabalho fixas e temporárias, onde se desenvolvem operações de apoio e execução de uma obra (NR 18, 1978). Outra definição é estabelecida na Norma Brasileira Regulamentadora (NBR) 1367/91 como áreas destinadas a execução e apoio dos trabalhos da indústria da construção e divide-se em áreas operacionais e áreas de vivência. As áreas operacionais são aquelas onde se desenvolvem atividades de trabalho ligadas diretamente à produção, enquanto que as áreas de vivência são aquelas destinadas a suprir as necessidades humanas básicas como alimentação, higiene pessoal, descanso, lazer, convivência e ambulatoriais, e, por isso devem ficar fisicamente separadas (ABNT, 1991).

O canteiro da obra deve ser dimensionado e executado levando-se em consideração as proporções e as características da mesma, por isso, os projetos das instalações dependem do tamanho da obra, do volume de material a ser armazenado, do número de funcionários, e dos períodos em que, tanto mão de obra, quanto material deverá estar na obra (SANEPAR, 2012).

Ainda que cada canteiro tenha suas especificidades de acordo com o empreendimento, existem normas brasileiras que regulamentam diretrizes de planejamento e organização para a instalação dessas áreas. Em síntese, o local para implantação do canteiro de obras deve ser preferencialmente em áreas planas, procurando evitar grandes movimentos de terra, de fácil acesso, livre de inundações, ventilado e com insolação adequada (ABNT, 1991).A obra de duplicação da 
ponte sobre o rio Itacaiúnas apresentava um canteiro de obras de apoio (Figura 5), localizado na margem direita do rio Itacaiúnas, sob as coordenadas UTM 22M 9.407.842 (N) e 708.164 (E).

Figura 5 - Canteiro de obras de apoio construído à margem direita do rio Itacaiunas. Marabá - PA.

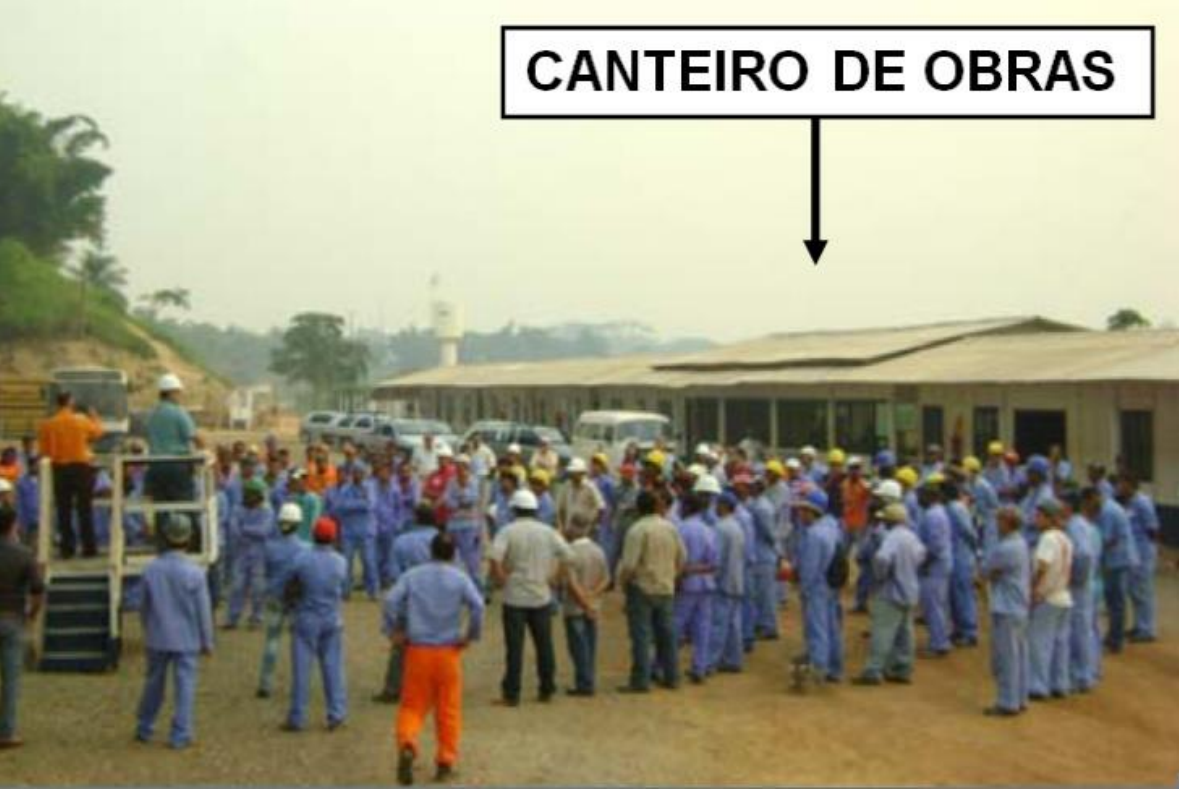

Fonte: DNIT (2009)

Tal empreendimento ocupava uma área total de $9.800 \mathrm{~m}^{2}$, sendo apenas $727,4 \mathrm{~m}^{2}$ de área construída que incluía escritórios, refeitório (sem preparação de alimentos), bebedouro, almoxarifado, ferramentaria (Figura 6a), banheiro/vestiário, laboratório, central de armação, central de forma, depósito de cimento, central de concreto, poço, um tanque séptico para armazenamento temporário dos efluentes provenientes dos banheiros, e uma caixa d'água (CMT ENGENHARIA, PCA, s/d). A ferramentaria foi instalada abaixo da ponte antiga (Figura 6b).

Figura 6 - a) Área de ferramentaria com as bancadas em funcionamento; b) localização sob a ponte de concreto.

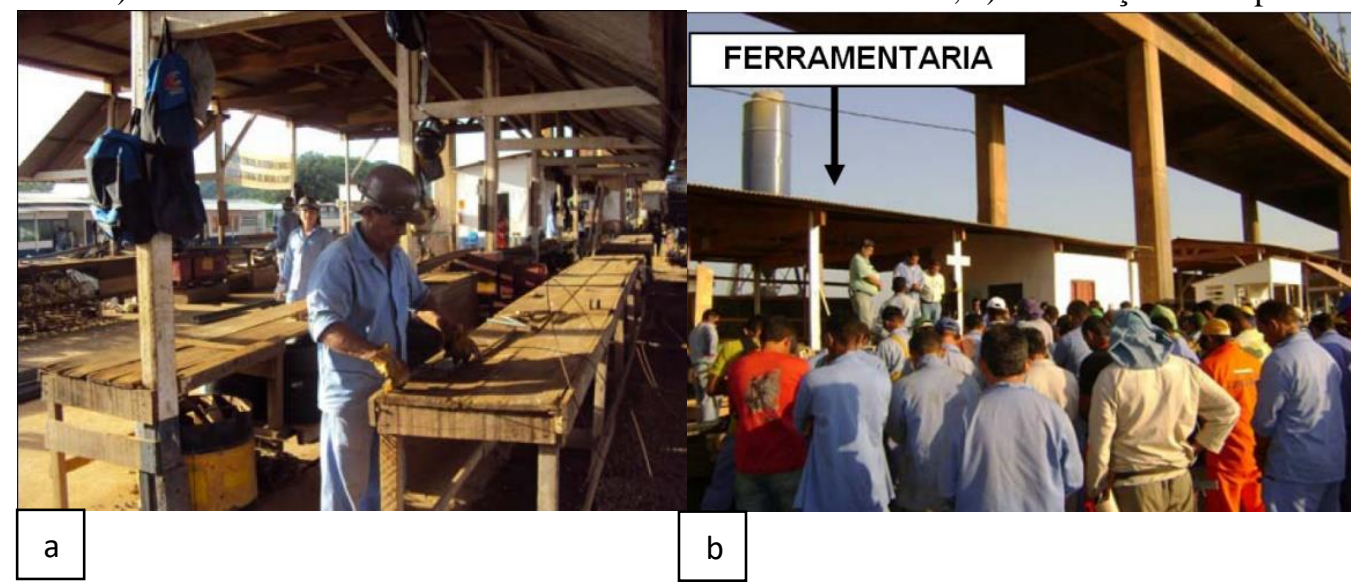

Fonte: DNIT (2009)

Outros aspectos evidenciados no canteiro de obras, foram a presença de um poço (Figura 7a) e o tanque sépticos provisórios (Figura 7b). O objetivo foi atender as necessidades básicas dos 
profissionais que ali atuaram, além de minimizar impactos ambientais que a ausência desses aspectos causaria.

Figura 7 - a) Fossa séptica instalada no canteiro de apoio; b) Fossa séptica instalada no canteiro de apoio. Marabá PA.

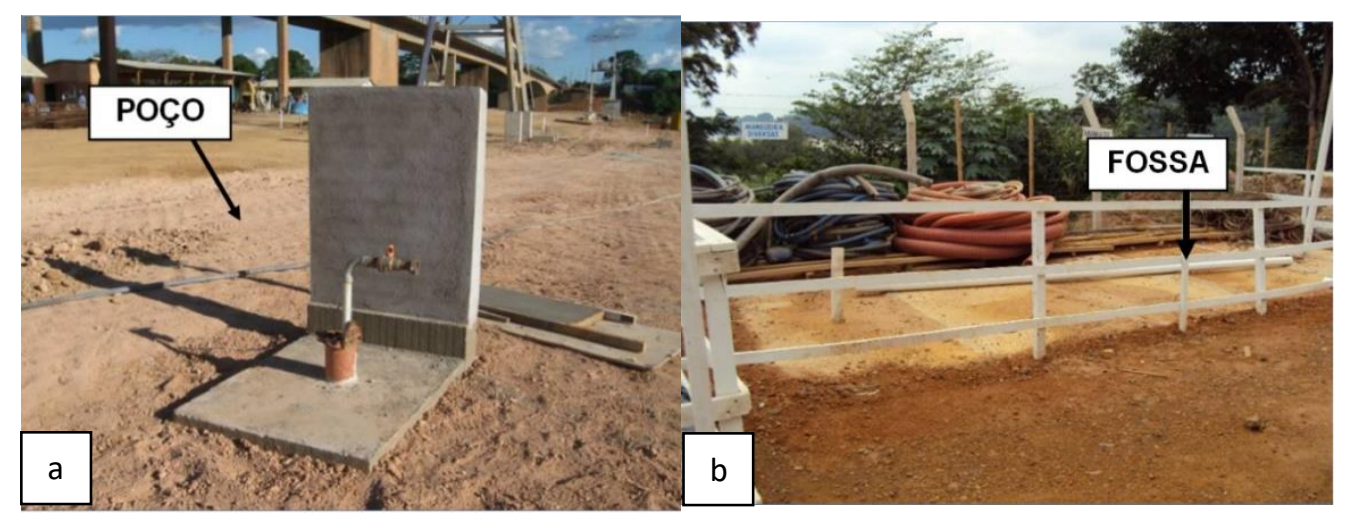

Fonte: DNIT (2009)

A área livre restante era usada para estacionamento, movimentação de veículos, e entrada e saída para disposição de equipamentos pesados utilizados principalmente na etapa de fundação da obra. Diariamente circulavam 250 funcionários, em uma jornada de 10 horas de trabalho diária, sendo que deste total, em torno de 30 pessoas trabalhavam nos escritórios e o restante nas frentes de serviço da obra.

Parte das atividades administrativas da obra funcionava dentro do canteiro, que contava com salas apropriadas para atender a seção técnica e superintendência. As outras tarefas como as de oficina, abastecimento de combustível e lava-jato foram executadas no canteiro central localizado a uma distância considerável do local da duplicação (CMT ENGENHARIA, PGRS, s/d).

\section{CENTRAL DE CONCRETO}

A central de concreto instalada no canteiro de obras em estudo possuía apenas um silo de armazenamento de cimento com capacidade para $100 \mathrm{~m}^{3}$ (Figura 8). Logo abaixo desse silo estava uma balança para cimento e bem próximo dela a mangueira que insere água dentro da betoneira.

Figura 8 - Central de concreto instalada no canteiro de apoio

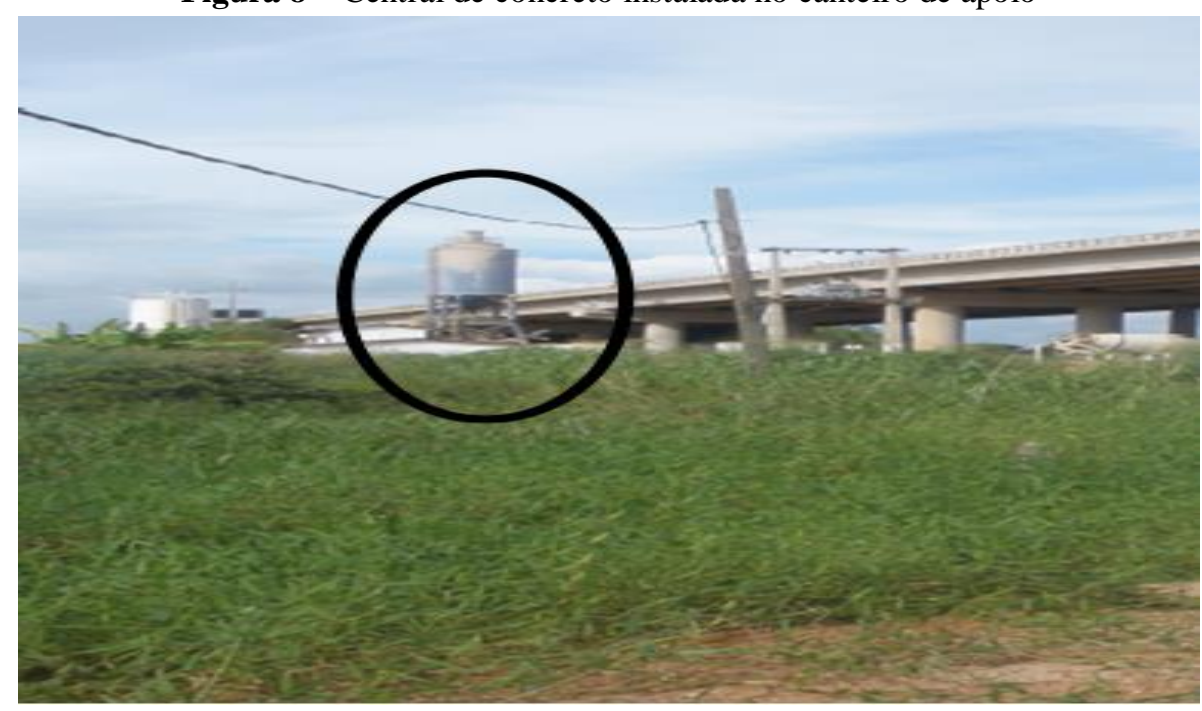

Fonte: DNIT, 2009 
Local de armazenamento dos agregados (bandeja), como areia e brita possui um compartimento para britas com granulometria distintas, assim como tipos distintos de areia. Abaixo dessa bandeja está localizada a balança de agregados. Além disso, a central de concreto possuía ainda duas esteiras transportadoras de agregados, que transportam os mesmos para o caminhão e por fim para uma cabine de operação e controle de produção (CMT ENGENHARIA, PCA, s/d).

A instalação desta central de concreto foi realizada com o objetivo de fornecer o concreto que seria utilizado na obra, dessa forma, havia grande emissão de particulados provenientes dessa atividade. Sobre isso, no Plano de Controle Ambiental (PCA) a empresa CMT Engenharia, responsável pela obra, se comprometeu em realizar aspersão diária de água no pátio do canteiro, principalmente nos horários considerados críticos.

Ainda no PCA apresentado ao órgão responsável pela liberação da licença ambiental para o canteiro de obras, a CMT Engenharia também se comprometeu em realizar a manutenção da central de concreto, para garantir o bom funcionamento e aumento da vida útil, bem como respeitar os prazos de troca do Filtro Manga para aumentar a eficiência do sistema de retenção de partículas e impedir a emissão de partículas acima dos níveis estabelecidos na legislação.

\section{LEGISLAÇÃO AMBIENTAL}

\section{POLÍTICA NACIONAL DO MEIO AMBIENTE (LEI No 6.938/1981)}

Criada em 31 de agosto de 1981 a Lei Federal №. 6.938, já alterada pela Lei $n^{\circ} 7.804 / 89$, dispõe sobre a Política Nacional do Meio Ambiente (PNMA), suas finalidades, mecanismos de formulação, aplicação e dá outras providências. Com o objetivo de preservar, melhorar e recuperar a qualidade ambiental do país através do SISNAMA (Sistema Nacional de Meio Ambiente), a PNMA cria o Conselho Superior do Meio Ambiente - CSMA, e também institui o Cadastro de Defesa Ambiental (BRASIL, 1981).

Como toda política a PNMA possui justificativa para sua existência, fundamentação teórica, metas e instrumentos, e prevê penalidades para aqueles que não cumprem as normas estabelecidas. Interfere nas atividades dos agentes econômicos e, portanto, a maneira pela qual é estabelecida influencia as demais políticas públicas, inclusive as políticas industriais e de comércio exterior (FARIAS, 2006).

A Política Nacional define o meio ambiente como o conjunto de condições, leis, influências e interações de ordem física, química e biológica, que permite, abriga e rege a vida em todos as suas formas (Art. $3^{\circ}$ ), e, considera-o como um patrimônio público, que, portanto, deve ser protegido. Para tal, em seu Art. $9^{\circ}$, esta Lei Federal institui alguns instrumentos com os quais visa garantir o alcance de seus objetivos. São eles:

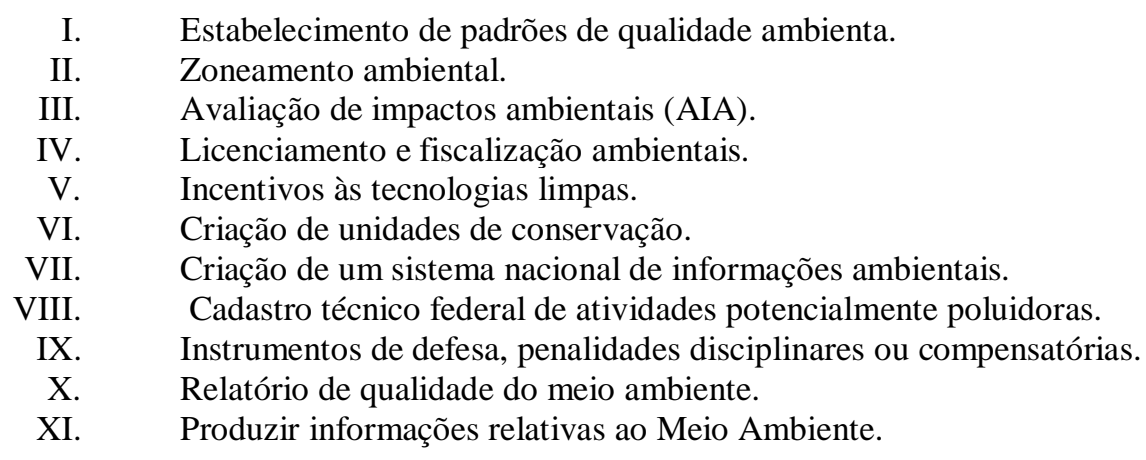


Essa resolução dispõe sobre os procedimentos relativos ao Estudo de Impacto Ambiental com o intuito de estabelecer as definições, responsabilidades, os critérios básicos e as diretrizes gerais para uso e implementação da Avaliação do Impacto Ambiental como um dos instrumentos da Política Nacional do Meio Ambiente (BRASIL, 1986). Ambiental:

Para as considerações iniciais dessa resolução, é preconizado um conceito para Impacto

\begin{abstract}
"qualquer alteração das propriedades físicas, químicas e biológicas do meio ambiente, causada por qualquer forma de matéria ou energia resultante das atividades humanas que, direta ou indiretamente, afetam: a saúde, a segurança e o bem-estar da população; as atividades sociais e econômicas; a biota; as condições estéticas e sanitárias do meio ambiente; a qualidade dos recursos ambientais." (Resolução CONAMA 001/1986, Art. nº 1).
\end{abstract}

Esta resolução também estabelece quais os empreendimentos e/ou atividades que dependem da elaboração do estudo de impacto ambiental e respectivo relatório de impacto ambiental (EIA/RIMA), ainda sujeito à aprovação pelo órgão competente, para a liberação da licença. São eles:

Estradas de rodagem com duas ou mais faixas de rolamento, ferrovias, portos e terminais de minério, petróleo e produtos químicos, aeroportos, oleodutos, gasodutos, minerodutos, linhas de transmissão de energia elétrica (acima de $230 \mathrm{KV}$ ), obras hidráulicas para exploração de recursos hídrico, extração de combustível fóssil (petróleo, xisto, carvão), aterros sanitários, processamento e destino final de resíduos tóxicos ou perigosos, usinas de geração de eletricidade (acima de $10 \mathrm{MW}$ ), complexo e unidades industriais e agroindustriais, distritos industriais e zonas estritamente industriais - ZEI, exploração econômica de madeira ou de lenha (áreas acima de 100 hectares, ou em áreas significativas do ponto de vista ambiental), projetos urbanísticos (acima de 100 hectares ou em áreas relevante interesse ambiental), qualquer atividade que utilize carvão vegetal, derivados ou produtos similares e, por último, projetos Agropecuários (áreas acima de 1000 hectares ou em áreas significativas do ponto de vista ambiental).

(Resolução CONAMA 001/1986, Art. nº 2).

NBR 12.284/1991 E 1367/1991

Esta norma dispões especificamente sobre áreas de vivência em canteiro de obras, estabelendo critérios e requisitos técnicos específicos de suas contruções. Para efeitos da mesma, considera canteiro de obras como áreas destinadas a execução e apoio dos trabalhos da indústria da construção e divide-se em áreas operacionais e áreas de vivência.

Nas áreas operacionais são desenvolvidas as atividades de trabalho ligadas diretamente à produção, enquanto que as áreas de vivência são destinadas às necessidades humanas básicas como alimentação, higiene pessoal, descanso, lazer, convivência e ambulatoriais, e, por isso devem ficar fisicamente separadas (ABNT, 1991).

Esta norma especifica alguns requisitos técnicos a respeito dos elementos presentes no canteiro de obras: as instalações sanitárias, vestiário, alojamentos, refeitórios, cozinha, lavanderia e área de lazer. Algumas especificações são apresentadas no Anexo B.

Para finalizar, a NBR 1367/1991, dá algumas disposições gerais, e dentre outras informações, estabelece que todo canteiro de obras com mais de 50 trabalhadores deve possuir além de uma pessoa treinada e habilitada para prestar primeiros socorros, deve possuir ambulatório, provido de medicamentos equipamentos e instrumentos para atendimento de emergências e consultas a serem realizadas, no mínimo, por um auxiliar de enfermagem que atenda todos os turnos de trabalho.

Ainda são estabelecidos critérios importantes, como por exemplo, a previsão de $80 \mathrm{~L}$ de água por dia para cada trabalhador, disponibilização de equipamentos de proteção contra incêndio e de combate ao fogo nos ares de vivência, instalação de latas de lixo em quantidade suficiente e compatível com o número de usuários, dentre outras informações gerais. 


\section{POLÍTICA NACIONAL DE RESÍDUOS SÓLIDOS (LEI N. 12.305/2010)}

Criada em 02 de agosto de 2010 a Lei Federal n. 12.305, institui a Política Nacional de Resíduos Sólidos (PNRS) e, reúne um conjunto de princípios, instrumentos, diretrizes, metas e ações adotados pelo Governo Federal, isoladamente ou em regime de cooperação com Estados, Distrito Federal, Municípios ou particulares, com vistas à gestão integrada e ao gerenciamento ambientalmente adequado dos resíduos sólidos (REIS, 2011).

A PNRS regulamentou a destinação final dos resíduos, revolucionou a gestão dos resíduos gerados e estabeleceu questões importantes (KONRAD; CALDERAN, 2011).

Para efeito desta lei os resíduos são classificados quanto sua origem (doméstico, de limpeza urbana, de estabelecimentos comerciais, dos serviços públicos de saneamento básico, industriais, serviço de saúde, construção civil, agrossilvopastoril, da mineração dentre outros), e quanto sua periculosidade (não perigosos e perigosos), sendo que estes últimos merecem tratamento especial dado pelos art. 37 a art. 41, da Lei $\mathrm{n}^{\circ}$ 12.305/2010, com exigências especiais às pessoas jurídicas que os operam (COPOLA, 2011).

Para o caso do objeto deste estudo, foi exigido o PGRS do empreendimento por este estar enquadrado no grupo das obras de construção civil. De modo geral, de acordo com esta lei, um PRGS deve apresentar como conteúdo mínimo:

I- Descrição do empreendimento ou atividade;

II- Diagnóstico dos resíduos sólidos gerados ou administrados, contendo a origem, o volume e a caracterização dos resíduos, incluindo os passivos ambientais a eles relacionados; III- observadas as normas estabelecidas pelos órgãos do Tisnam, do SNVS e do Suas e, se houver, o plano municipal de gestão integrada de resíduos sólidos:

a) explicitação dos responsáveis por cada etapa do gerenciamento de resíduos sólidos;

b) definição dos procedimentos operacionais relativos às etapas do gerenciamento de resíduos sólidos sob responsabilidade do gerador;

IV- identificação das soluções consorciadas ou compartilhadas com outros geradores;

V- ações preventivas e corretivas a serem executadas em situações de gerenciamento incorreto ou acidentes;

VI- metas e procedimentos relacionados à minimização da geração de resíduos sólidos e, observadas as normas estabelecidas pelos órgãos do Sisnama, do SNVS e do Suasa, à reutilização e reciclagem;

VII- se couber, ações relativas à responsabilidade compartilhada pelo ciclo de vida dos produtos;

VIII- medidas saneadoras dos passivos ambientais relacionados aos resíduos sólidos;

IX- periodicidade de sua revisão, observado, se couber, o prazo de vigência da respectiva licença de operação a cargo dos órgãos do Sisnama.

(Lei 12.305/200 - Art. n 21).

\section{RESOLUÇÃO CONAMA N.307/2002}

Mediante a necessidade de redução efetiva dos impactos ambientais gerados pelos resíduos oriundos da construção civil, principalmente no que diz respeito à sua disposição em locais inadequados, o que contribui para a degradação da qualidade ambiental, a resolução ${ }^{\circ}$ 307/02 surgiu para estabelecer diretrizes, critérios e procedimentos para a gestão dos resíduos da construção civil, e disciplinar as ações necessárias de forma a minimizar os impactos ambientais (BRASIL, 2002). A gestão integrada dos resíduos da construção civil é apresentada por esta resolução como instrumento necessário para propiciar os benefícios de ordem econômica, social e ambiental desejados, disciplinando as ações necessárias de modo a minimizar os impactos ambientais (CARELI, 2008).

Para efeito desta resolução, inicialmente são definidos alguns termos, dentre eles: 
I - Resíduos da construção civil: são os provenientes de construções, reformas, reparos e demolições de obras de construção civil, e os resultantes da reparação e da escavação de terrenos, tais como: tijolos, blocos cerâmicos, concreto em geral, solos, rochas, metais, resinas, colas, tintas, madeiras e compensados, forros, argamassa, gesso, telhas, pavimento asfáltico, vidros, plásticos, tubulações, fiação elétrica etc., comumente chamados de entulhos de obras, caliça ou metralha.

II - Geradores: são pessoas, físicas ou jurídicas, públicas ou privadas, responsáveis por atividades ou empreendimentos que gerem os resíduos definidos nesta Resolução.

III - Gerenciamento de resíduos: é o sistema de gestão que visa reduzir, reutilizar ou reciclar resíduos, incluindo planejamento, responsabilidades, práticas, procedimentos e recursos para desenvolver e implementar as ações necessárias ao cumprimento das etapas previstas em programas e planos.

(Resolução CONAMA 307/2002, Art. n²).

\section{MATERIAL E MÉTODOS}

Os materiais utilizados para aquisição dos dados desse trabalho foram: trena em fibra de vidro graduada em metros (total $30 \mathrm{~m}$ ) para mensurar as distâncias entre cada ponto e entre as pilastras da ponte para o início das áreas; aparelho Global Positioning System (GPS) da marca GARMIN, modelo $73 \mathrm{~S}$, com precisão de $3 \mathrm{~m}$ para demarcar as coordenadas geográficas das duas áreas e das oito parcelas em estudo.

Os procedimentos metodológicos foram divididos em duas etapas distintas: (I) ex situ, que foi a busca por dados primários e secundários de fontes pretéritas como dissertações, monografias, artigos, livros, teses, e endereços eletrônicos que estivessem envolvidos com o objeto desse trabalho.

(II) In situ que foi constituído por 6 visitas a área de estudo, para registros fotográficos do local e elaboração do memorial; estabelecimento das áreas $\left(\begin{array}{lll}1 & \text { e } & 2\end{array}\right)$ escolhidas previamente devido à localização de estruturas de suporte edificadas pela construtora que executou a obra; divisão das mesmas em parcelas de $10 \mathrm{~m}$ x $20 \mathrm{~m}$; estabelecimento de minitrincheiras $(0,5 \times 0,5 \mathrm{~m})$; coleta de amostras do solos dessas áreas nas profundidades: $0-10 \mathrm{~cm} ; 10 \mathrm{~cm}-20 \mathrm{~cm} ; 20 \mathrm{~cm}-40 \mathrm{~cm}$; coleta da fauna de superfície (edáfica).

\section{FISIOGRAFIA DO MUNICÍPIO}

O município de Marabá pertence à mesorregião Sudeste Paraense e à microrregião Marabá (Figura 9) e está localizada à margem esquerda do rio Tocantins. A população total do município, de acordo com o censo 2010, contava com 233.669 habitantes em uma área de $15.128 \mathrm{~km}^{2}$ (IBGE, 2010).

Figura 9 - Mapa de localização do Município de Marabá, Pará.

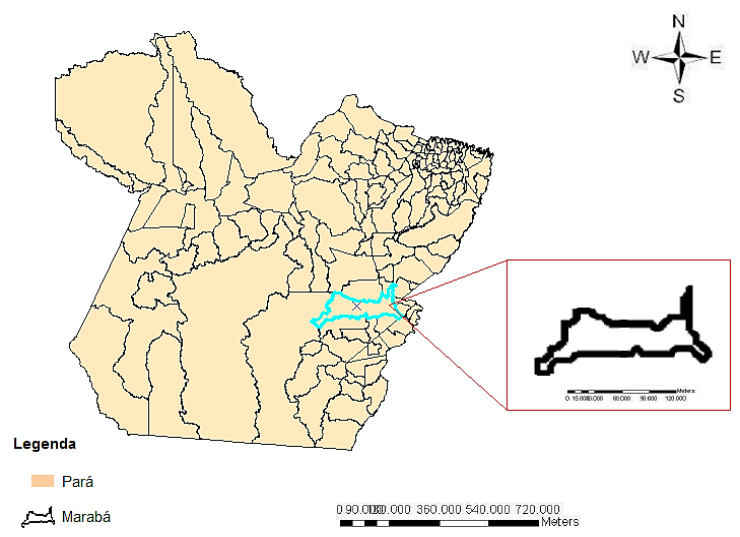

Fonte: autores (2015). 
As coordenadas geográficas da sede municipal são $05^{\circ} 21^{\prime}$ '54” de Latitude Sul, e $04^{\circ} 07^{\prime}$ '24" de Longitude a Oeste de Greenwich. Limita-se ao norte com os municípios de Itupiranga, Rondon do Pará, Nova Ipixuna e Novo Repartimento, a leste com os municípios de Bom Jesus do Tocantins, São João do Araguaia, São Domingos do Araguaia e São Geraldo do Araguaia, ao sul com os municípios de Curionópolis, Parauapebas, Eldorado dos Carajás e São Félix do Xingu, por fím, a oeste com o município de São Félix do Xingu (PARÁ, 2013).

O clima do município de Marabá caracteriza-se como equatorial, quente e úmido, segundo a classificação Koppen. O município apresenta temperatura do ars médias mensais entre $22,9^{\circ} \mathrm{Ce} 32^{\circ} \mathrm{C}$, e média anual de $26^{\circ} \mathrm{C}$. A umidade relativa do ar é elevada (entre $73 \%$ a 93\%), oscilando entre as estações mais chuvosas (janeiro a março), e mais seca (julho a setembro). O índice pluviométrico está em torno de $2.000 \mathrm{~mm} / \mathrm{ano}$, e a insolação média é de 2.400 horas anuais (RAIOL, 2010).

A rede hidrográfica do município é representada principalmente pela bacia do rio Itacaiúnas, afluente pela margem esquerda do rio Tocantins, cuja foz encontra-se a sede municipal. Cortando o seu território com direção geral oeste/leste, apresenta como principais tributários, pela margem direita os rios: Madeira, Parauapebas, da Onça, e Vermelho. Pela margem esquerda, destacam-se os rios Aquiri, Tapirapé, Preto e os igarapés Cinzeiro e Grota do Café (PARÁ, 2013). O rio Itacaiúnas percorre mais de $200 \mathrm{~km}$ o território marabaense, enquanto que p rio Tocantins o faz apenas em um trecho de $50 \mathrm{~km}$, contudo foi este de menor abrangência que permitiu a ocupação e colonização inicial do município quando permitiu a navegação entre Marabá e a capital do estado, Belém (ALMEIDA, 2008).

Como ponto central da região de entorno do baixo e médio Tocantins, o município de Marabá apresenta bastante diversidade em relação à cobertura vegetal, com predominância de Floresta Densa ao Norte do Município. Pode-se também descrever a área como situada na periferia da floresta amazônica, rodeada, do sudoeste a nordeste, por áreas de encontro entre a floresta tropical e áreas de cerrado, assim como pelas matas de transição encontradas no Maranhão (MARABÁ, 2011).

Em trechos que margeiam o rio Tocantins encontra-se também a Floresta Densa dos terraços, Florestas Ciliares e Matas de Galeria, acompanhando os cursos d'água de menor porte. Nota-se também, a presença de Campos Artificiais destinados à atividade pecuária, onde ocorreram

desmatamentos. Já na área urbana do município predominam poucas florestas antrópicas (RAIOL, 2010).

Em regiões tropicais, os solos, de maneira geral, apresentam-se bastante intemperizados e lixiviados, possuindo baixa fertilidade natural. Nesses solos, é a matéria orgânica que representa a maior fonte de nutrientes para o crescimento vegetal (CORREIA: OLIVEIRA, 2000; MACEDO, 2004; VICENTE et al., 2010). O solo, na Amazônia, apresenta aspectos muito comuns como: baixa fertilidade natural e alta saturação de alumínio trocável. A caolinita é o mineral predominante na fração argila, e a capacidade de troca de cátions e a saturação de bases são baixas. $\mathrm{O}$ estoque de nutrientes é baixo, limitando a produção agrícola e florestal (PEREIRA JÚNIOR, 2011).

Os solos do município de Marabá são classificados em: Latossolo Vermelho-Amarelo distrófico de textura média e argilosa, Podzólico Vermelho-Amarelo de textura argilosa, Areias Quartzosas Hidromórficas, Solos Aluviais e Solos Litólicos, com predominância do solo Podzólico Vermelho de textura argilosa. Na área urbana, no núcleo São Félix predomina a Areia Quartzosa Hidromórficas e, em Morada Nova o Latossolo Vermelho. Já na Cidade Nova, Nova Marabá e Marabá Pioneira, caracteriza-se o tipo podzólico vermelho (RAIOL, 2010). No que diz respeito ao relevo, suas formas estão englobadas pela unidade morfoestrutural denominada de Depressão Periférica do Sul do Pará, onde dominam os planaltos amazônicos rebaixados e dissecados, e as áreas colinosas, com áreas montanhosas mais ao Sul (PARÁ, 2013).

A topografia de Marabá apresenta as maiores altitudes da região do Sudeste do Estado do Pará, devida à presença das serras dos Carajás, Sereno, Buritirama, Paredão, Encontro, Cinzento e Misteriosa (RAIOL, 2010). Também por isso, o município apresenta uma ampla variação em seus 
valores altimétricos, com as cotas máximas nas proximidades da Serra dos Carajás, e altimétricos menores, localizados às margens do rio Tocantins.

Em relação à área urbana, os pontos mais elevados situam-se na Cidade Nova, nas proximidades do aeroporto, na Nova Marabá, nas proximidades da interseção da rodovia Transamazônica-BR 230 com a rodovia PA-150 (ALMEIDA, 2008). Por estar disposto na interseção entre os rios Itacaiúnas e Tocantins, o núcleo Marabá Pioneira sofre com enchentes anuais em alguns bairros como Santa Rita, Santa Rosa e Cabelo Seco.

\section{AMOSTRAGEM DO SOLO}

Foram utilizadas duas grandes áreas: A1 e A2 (Figura 10) de 10mx20m, totalizando 200m². Cada área foi subdividida em 4 parcelas $(10 \mathrm{~m} \mathrm{X} 5 \mathrm{~m})$ totalizando $50 \mathrm{~m}^{2}$, em cada uma das parcelas

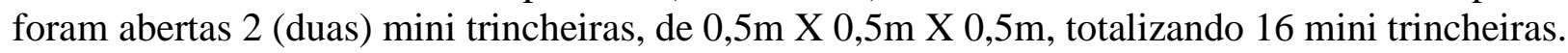

Figura 10 - Disposição das áreas 1 e 2 sob a Ponte do Rio Itacaiúnas, margem direita. Marabá - PA.

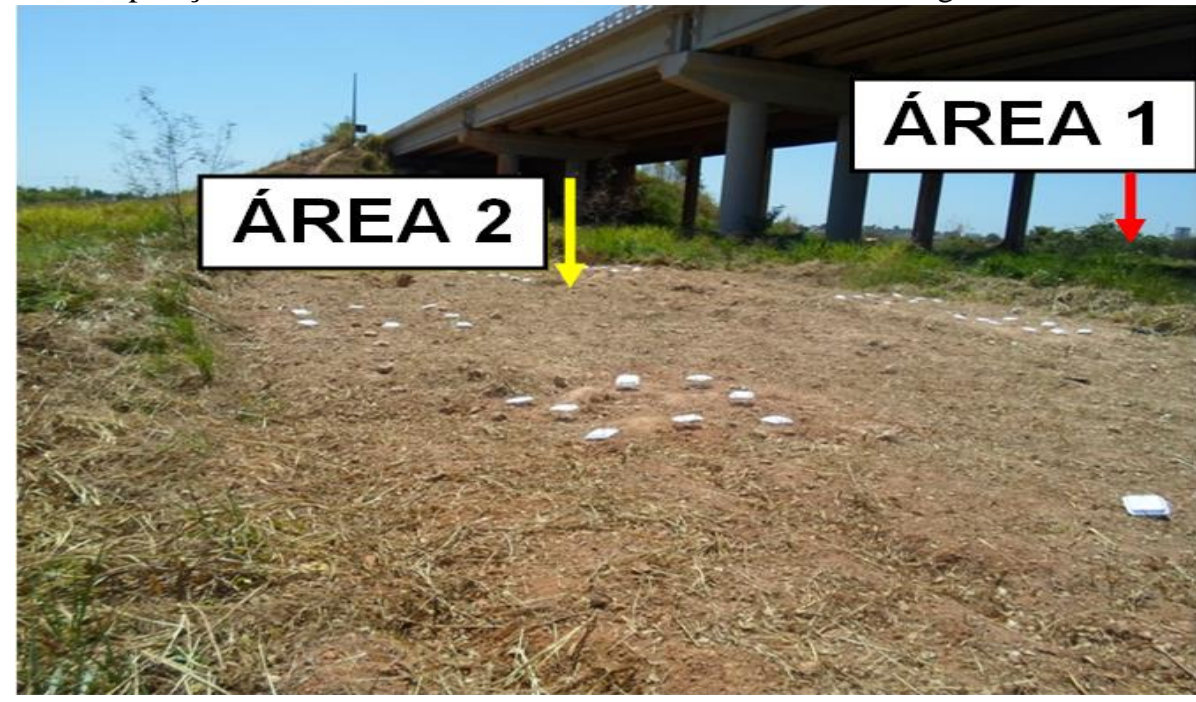

Fonte: autores (2015).

A área 1, localiza-se à 7,70m à direita da segunda pilastra de sustentação da ponte (sentido à margem do rio e do vão da ponte para fora). Este espaçamento foi escolhido devido a melhor facilidade de manipulação do solo que, neste perímetro, encontrava-se mais úmido e menos compactado do que em outra área mais próxima do talude da ponte ou da pilastra.

A área 2, estava localizada na extremidade oposta do vão da ponte que foi utilizado como referencial para a área 1 , no entanto, devido à presença da ponte antiga que fica ao lado, não foi possível manter uma posição paralela entre as duas áreas, pois as pilastras da ponte antiga atrapalharam a demarcação desta área. Desse modo foi necessário recuar $8,2 \mathrm{~m}$ no sentido contrário à margem do rio, em direção ao talude, para que A2 ficasse no centro, entre as duas pilastras de sustentação da ponte antiga.

Para a coleta das amostras foram estabelecidas três profundidades diferentes: 0 -10cm, 10 $20 \mathrm{~cm}$ e de $20-40 \mathrm{~cm}$ (Figura 11a), sentido da linha de nivelamento do terreno para o fundo da mini trincheira). Logo após, escarificou-se, com colher de pedreiro (Figura 11b), a parede interna selecionada aleatoriamente, alternando em cada mini trincheira, para que não fossem coletadas em uma única direção apenas, sendo efetuada debaixo para cima para evitar contaminação das amostras, em cada uma das coletas efetuadas. Após coletadas as amostras foram embaladas em sacos plásticos de $500 \mathrm{~g}$, etiquetadas para identificação das áreas e parcelas onde foram coletadas (Figura 11c). 
Figura 11 - a) Mini trincheira com as profundidades utilizadas para coleta de amostras do solo sob a Ponte do Rio Itacaiúnas, Marabá - Pará.

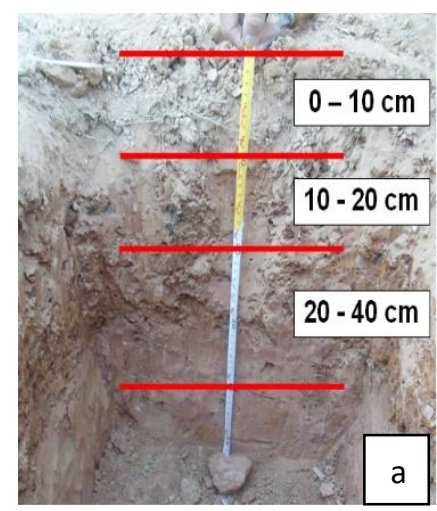

a

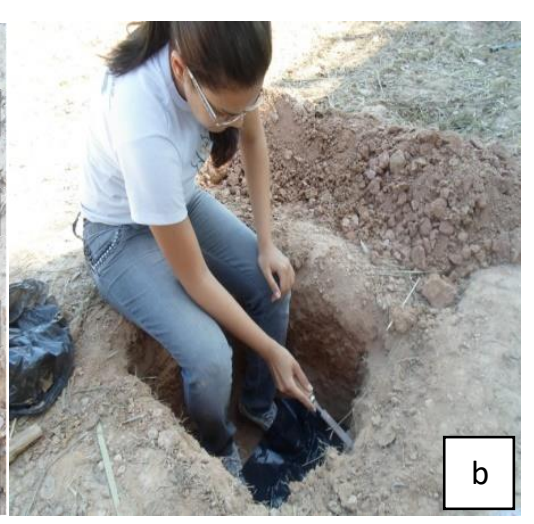

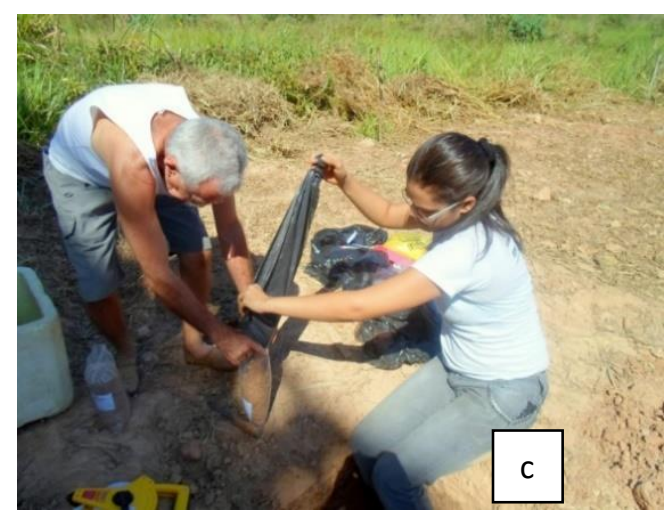

Fonte: autores (2015).

Por serem apenas duas pessoas trabalhando na escarificação das minis trincheiras, a coleta foi realizada em dois dias: 7 e 8 de agosto de 2013. Sendo que apenas 12 do total das amostras ficaram para o segundo dia. Após a coleta, as amostras foram conduzidas ao laboratório de física do solo do Museu Paraense Emílio Goeldi (MPEG), onde foram secas ao ar, destorroadas e tamisadas em peneiras (malha $=2 \mathrm{~mm}$ ), para separação das frações calhau e cascalho da fração terra fina seca ao ar (TFSA).

\section{TRATAMENTO ESTATÍSTICO DOS DADOS}

O tratamento dos dados foi realizado com usos de planilhas eletrônicas contidas nos softwares estatísticos TAL 4.2 (SUNG, 1996 -2002), Excel 2007 (MICROSOFT CORPORATION, 2016) e BioEstat 5.0 (AYRES et al., 2007). O TAL 4.2 foi utilizado para identificar a classe textural dos solos analisados a partir dos níveis de areia, silte e argila. Através do Excel foi possível estabelecer as médias dos parâmetros analisados, bem como a montagem dos seus respectivos gráficos. O BioEstat é um programa de análise bioestatística uni e multivariada muito utilizado no Brasil principalmente no estado do Pará, que surgiu com objetivo de diminuir a complexidade de se trabalhar com dados obtidos em uma pesquisa.

Através desse software, foi possível obter as médias, por profundidades, nos solos dos sistemas analisados, quanto à granulometria, classificação textural, carbono, matéria orgânica, nitrogênio total, fósforo total, $\mathrm{pH}, \mathrm{CTC}$, sódio, deste os outros parâmetros analisados, nos quais foi aplicada a estatística descritiva, análise de variância (ANOVA), a dois critérios, seguida do Teste de Tukey a 5\% de significância.

\section{RESULTADOS E DISCUSSÃO}

\section{CLASSIFICAÇÃO TEXTURAL DO SOLO}

A partir das frações de argila areia e silte para cada profundidade, das duas áreas analisadas, obteve-se um total de seis classes texturais distintas destacando a área 1(Figura 14a), com o maior número: franco argilo arenoso, franco argiloso, argiloso, franco siltoso, argilo arenoso e muito argiloso; $\mathrm{A}_{2}$ (Figura 14b) mostrou pouca variação com apenas duas classes: argiloso e franco argiloso. 
Figura 14 - a) Percentual para cada classe textural encontrada na área 1 sob a Ponte do Rio Itacaiúnas, lado esquerdo da ponte; b) área 2, sob a Ponte do Rio Itacaiúnas, lado direito da ponte, Marabá- Pará.

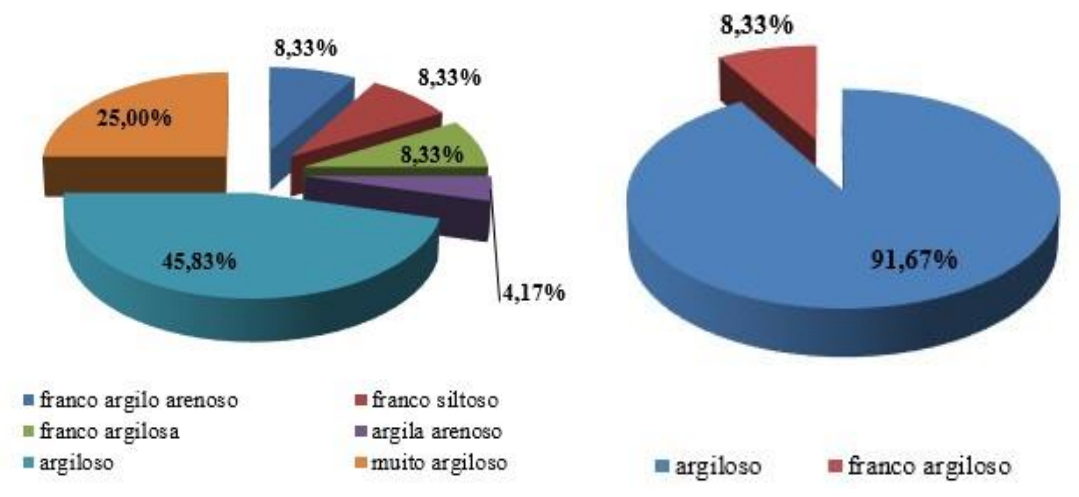

Fonte: autores (2015).

Os dados analisados indicaram que, em ambas as áreas, há ocorrência de duas classes texturais: argiloso e franco argiloso, sendo que, na área 2, a presença desse tipo de solo é mais efetiva $(91,67 \%)$. Sobre a presença e função desse tipo de solo, foram efetuados dois estudos por Fearnside e Leal Filho (2001), e Kiehl (1979), e ambos concluiram que os solos argilosos, além de apresentar maior capacidade de retenção catiônica, mostraram-se positivamente relacionados com a matéria orgânica, no sentido de apresentarem uma correlação positiva, quanto maior a quantidade de argila, maior será a quantidade de carbono e matéria orgânica. No presente estudo, esta é a justificativa para as concentrações de carbono e matéria orgânica encontradas para as duas áreas, já que a classe textural argiloso foi a que apresentou maior predominância nas duas áreas.

\section{ATRIBUTOS QUÍMICOS}

\section{PH, CARBONO ORGÂNICO, MATÉRIA ORGÂNICA, NITROGÊNIO E RELAÇÃO $\mathrm{C} / \mathrm{N}$}

Quanto ao potencial hidrogeniônico $(\mathrm{pH})$, a análise dos dados obtidos, indicou uma tendência para alcalinização na área 2 (Tabela 3).

Tabela 3 - Valores das médias obtidas para o potencial hidrogeniônico das duas áreas, em cada parcela e profundidade. Marabá - PA. Conclusão.

\begin{tabular}{ccccc|cc|c|c|c}
\hline & \multicolumn{4}{c}{ ÁREA 1 } & \multicolumn{4}{c}{ ÁREA 2 } \\
\hline Profundidades (cm) & $\mathbf{P}_{\mathbf{1}}$ & $\mathbf{P}_{\mathbf{2}}$ & $\mathbf{P}_{\mathbf{3}}$ & $\mathbf{P}_{\mathbf{4}}$ & $\mathbf{P}_{\mathbf{1}}$ & \multicolumn{1}{c}{$\mathbf{P}_{\mathbf{2}}$} & \multicolumn{1}{c}{$\mathbf{P}_{\mathbf{3}}$} & $\mathbf{P}_{\mathbf{4}}$ \\
\cline { 2 - 9 } $0-10$ & 6.78 & 6.74 & 5.36 & 6.97 & 8.45 & 7.79 & 8.25 & 6.29 \\
$10-20$ & 6.31 & 5.91 & 5.36 & 5.59 & 8.75 & 6.82 & 7.43 & 7.31 \\
$20-40$ & 5.51 & 4.83 & 5.26 & 5.82 & 8.11 & 6.35 & 6.34 & 7.69 \\
\hline
\end{tabular}

Fonte: autores (2015).

Os dados obtidos e analisados indicaram que os valores para o pH, na área 1, mantiveram-se dentro dos padrões para os solos amazônicos (4,5 a 6,5). Porém, na área 2, o pH mostrou tendência para elevação, o que torna o solo alcalino para esses padrões, em profundidades distintas. Sobre as variações acerca do $\mathrm{pH}$, foi efetuado um estudo em Aurora do Pará, na Fazenda Experimental Tramontina, por Pereira Júnior (2011) comprovou que as variações no pH interferem com a CTC em relação a oferta de nutrientes às plantas e compromete a fertilidade do solo. Isso indica que os impactos ambientais no solo, foram mais efetivos na área 2. 
Os teores de carbono orgânico, relacionando as duas áreas e considerando os valores brutos encontrados por mini trincheiras, variaram entre 2,41 a $28,11 \mathrm{~g} / \mathrm{kg}$, e, não apresentaram efeitos estatísticos significantes quando analisados por profundidade entre as duas áreas. Tratando-se da média geral de cada área, independente da profundidade, $\mathrm{A}_{1}$ apresentou menor teor de carbono, 9,44 $\mathrm{g} / \mathrm{Kg}$ contra 10,81 g/kg em A2 (Tabela 4).

Tabela 4 - Valores das médias obtidas para o carbono orgânico das duas áreas, em cada parcela e profundidade. Marabá - PA.

\begin{tabular}{ccccccccc}
\hline & \multicolumn{4}{c}{ ÁREA 1 (g/kg) } & \multicolumn{3}{c}{ ÁREA 2 $(\mathbf{g} / \mathbf{k g})$} \\
\hline Profundidades $(\mathbf{c m})$ & $\mathbf{P}_{\mathbf{1}}$ & $\mathbf{P}_{\mathbf{2}}$ & $\mathbf{P}_{\mathbf{3}}$ & $\mathbf{P}_{\mathbf{4}}$ & $\mathbf{P}_{\mathbf{1}}$ & $\mathbf{P}_{\mathbf{2}}$ & $\mathbf{P}_{\mathbf{3}}$ & $\mathbf{P}_{\mathbf{4}}$ \\
\hline $\mathbf{0 ~ - ~ 1 0}$ & 5.02 & 6.43 & 21.49 & 18.47 & 9.04 & 11.25 & 13.05 & 11.45 \\
$\mathbf{1 0 - 2 0}$ & 5.62 & 4.22 & 13.65 & 11.25 & 10.04 & 9.84 & 9.44 & 14.46 \\
$\mathbf{2 0 - 4 0}$ & 4.02 & 8.84 & 6.63 & 7.63 & 9.64 & 6.83 & 11.45 & 13.25 \\
\hline
\end{tabular}

Estudo realizado sobre estoque de carbono em Latossolos, Argissolos e Neossolos, no sudoeste da Amazônia, de acordo com os resultados obtidos, conclui que o teor de carbono orgânico no solo encontra-se na composição da matéria orgânica $(\mathrm{MO})$ até $30 \mathrm{~cm}$, onde há diferentes estágios de decomposição (BELIZÁRIO, 2008).

Baseando-se nisso esperava-se que os maiores valores para o carbono fossem encontrados nas camadas superiores, no entanto, como visto na Tabela 04, algumas parcelas apresentaram comportamento diferenciado (como $\mathrm{P}_{2} / \mathrm{A}_{1}, \mathrm{P}_{1} / \mathrm{A}_{2}, \mathrm{P}_{3} / \mathrm{A}_{2}, \mathrm{P}_{4} / \mathrm{A}_{2}$ ) nas quais o teor de carbono das camadas inferiores mostra-se maiores do que na camada superficial. No entanto, na média geral, por profundidade, os valores apresentaram o comportamento esperado no qual o teor de carbono diminui com o aumento da profundidade.

Na pesquisa realizada por Machado (2001), sobre o manejo de matéria orgânica realizado em solos tropicais, os dados obtidos indicaram que o carbono orgânico é utilizado como fonte de energia pela comunidade de invertebrados e, isso pode ter ocorrido bioturbação nas últimas camadas, o que pode ter elevado os teores desse elemento mineral nos solos desse sistema e nessa profundidade. No presente estudo, a melhor explicação para o aumento do teor de Corg nas camadas mais inferiores é essa, no entanto, esses invertebrados, conhecidos como "engenheiros do ecossistema" não foram objetos deste estudo.

Outras justificativas para esta situação inversa no teor de carbono é que pode ter havido lixiviação deste componente para as camadas inferiores, ou, ela ainda pode estar relacionada à forma como o material alóctone foi removido de outra área, no sentido que possa ter sido removido apenas da camada superficial de uma determinada região, nesse caso suas características não condizem com as de um perfil de solo mais inferior (Figura 26).

Figura 26 - Médias obtidas para o carbono orgânico nas duas áreas entre as parcelas e profundidades analisadas. Marabá - PA.

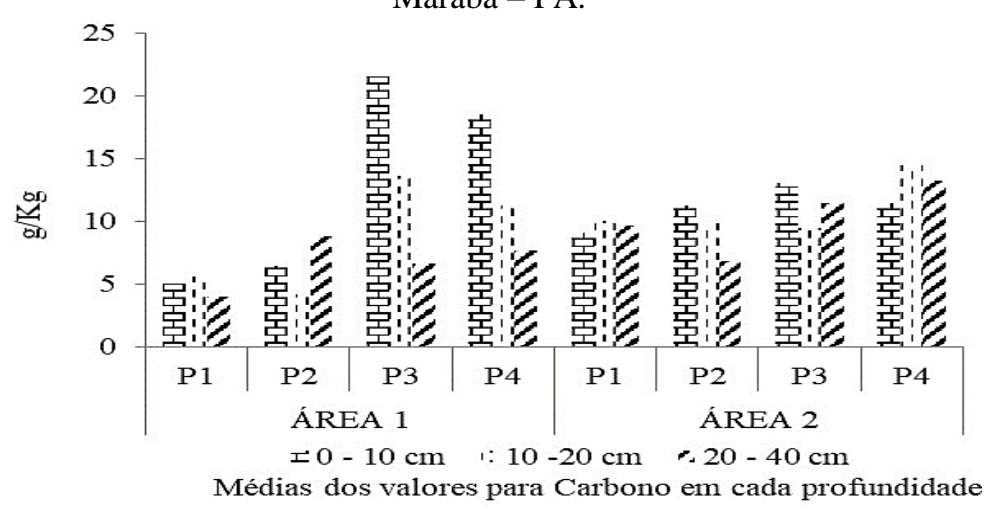

Fonte: autores (2015) 
Após a análise dos dados, pôde-se observar que em $\mathrm{P}_{1}$ e $\mathrm{P}_{2}$ da $\mathrm{A}_{1}$ apresentaram os menores valores para o carbono, principalmente na profundidade $0-10$, enquanto que as parcelas 3 e 4 apresentaram os picos mais altos nesta mesma profundidade. Sobre $\mathrm{A}_{2}$ observou-se que o teor de carbono pouco variou entre as profundidades, e, também foi onde o comportamento deste componente apresentou-se diferenciado. Novamente isso pode ser explicado pelo fato de esta ser a área que recebeu modificação mais recente pela entrada de material alóctone e pela influência da central de concreto que próxima dali esteve instalada.

Estudo efetuado em solos de diferentes texturas por Castro (2008), quanto ao estoque de carbono orgânico, mostrou que a ordem de predominância para as maiores concentrações de carbono foi encontrada na fração argiloso, seguida pela fração silte e em último lugar na areia. No presente estudo os valores das médias de Corg para as classes texturais encontradas também mostrou este mesmo arranjo, apesar de não ter apresentado a fração areia na classificação das profundidades. A ordem de concentração em cada área foi:

$\mathbf{A}_{1}:$ argiloso $>$ muito argiloso $>$ franco siltoso $>$ franco argilo arenoso $>$ argila arenoso $>$ franco argiloso.

A2: franco argiloso > argiloso.

Os valores de matéria orgânica (MO) encontrado nas duas áreas variaram entre 4,15 g/kg a $48,47 \mathrm{~g} / \mathrm{Kg}$ e, não apresentaram efeitos estatísticos significantes quando analisados por profundidade entre as duas áreas (Tabela 5).

Tabela 5 - Valores das médias obtidas para a matéria orgânica das duas áreas, em cada parcela e profundidade. Marabá - PA.

\begin{tabular}{|l|c|c|c|c|c|c|c|c|}
\hline & \multicolumn{4}{|c|}{ ÁREA 1 (g/kg) } & \multicolumn{4}{c|}{ ÁREA 2 (g/kg) } \\
\hline Profundidades & $\mathbf{P}_{\mathbf{1}}$ & $\mathbf{P}_{\mathbf{2}}$ & $\mathbf{P}_{\mathbf{3}}$ & $\mathbf{P}_{\mathbf{4}}$ & $\mathbf{P 1}$ & $\mathbf{P}_{\mathbf{2}}$ & $\mathbf{P}_{\mathbf{3}}$ & $\mathbf{P}_{\mathbf{4}}$ \\
\hline $0-10 \mathrm{~cm}$ & 8.65 & 11.08 & 37.04 & 31.85 & 15.58 & 19.39 & 22.5 & 19.73 \\
\hline $10-20 \mathrm{~cm}$ & 9.69 & 7.27 & 23.54 & 19.39 & 17.31 & 16.96 & 16.27 & 24.93 \\
\hline $20-40 \mathrm{~cm}$ & 6.92 & 15.23 & 11.42 & 13.16 & 16.62 & 11.77 & 19.73 & 22.85 \\
\hline
\end{tabular}

Legenda: $\mathrm{P}=$ profundidade

Fonte: autores (2015)

Sobre os valores médios da MO, Carvalho et al. (1999), efetuaram estudo em solo podzólico, e concluiram que os valores médios para o teor de matéria orgânica diminuíram em profundidade. Tal comportamento foi mais evidente na camada superficial para a subsequente e, estava relacionado à deposição superficial de resíduos animais e vegetais que a matéria orgânica representa, bem como pela natureza superficial das raízes da maioria dos vegetais.

Na pesquisa realizada em Marabá, os valores obtidos para a MO, apresentaram esse mesmo comportamento não estavam relacionados aos mesmos fatores, já que as duas áreas não apresentavam vegetação arbustiva. Nesse sentido, pode-se afirmar que o teor de matéria orgânica encontrado nas áreas pesquisadas, está relacionado à presença de herbáceas, também conhecida como capim, que predominava as áreas em termos de vegetação, ou então pode estar relacionado à MO já presente no solo alóctone que foi introduzido no local.

Outra observação efetuada a partir dos dados analisados sobre MO, assim como ocorreu para os valores do carbono, apresentou comportamento diferenciado, em algumas parcelas $\left(\mathrm{P}_{1} / \mathrm{A}_{1}, \mathrm{P}_{1} / \mathrm{A}_{2}\right.$, $\mathrm{P}_{4} / \mathrm{A}_{2}$ ), no qual o teor dela, aumentou em profundidade. A este desempenho também se justifica os mesmos argumentos que foram apresentados para o carbono.

Na relação da MO com a classificação textural, pesquisas realizadas por Araújo et al. (2012), e Belizário (2008), indicaram que, quanto maior o teor de argila, maior será a concentração da matéria orgânica. Nesse caso, os dados obtidos em Maraba - PA, indicaram que, na área 1, as maiores concentrações de MO encontravam-se nas classes argiloso $(22,91 \mathrm{~g} / \mathrm{Kg})$ e muito argiloso $(13,5 \mathrm{~g} / \mathrm{Kg})$. Já na área 2 a maior concentração de MO encontrada foi na franco argiloso $(23,19$ g/Kg) e em seguida pela classe de solo argiloso $(18,22 \mathrm{~g} / \mathrm{Kg})$. 
Para o teor de nitrogênio total ( $\mathrm{N}_{\text {Total }}$ ), a análise dos dados obtidos indicou que não houve tendências de variações quanto aos valores médios encontrados, nas duas áreas e nas profundidades analisadas (Tabela 6).

Tabela 6 - Valores das médias obtidas para o nitrogênio total das duas áreas, em cada parcela e profundidade.

\begin{tabular}{lcccccccc}
\hline & \multicolumn{4}{c}{ ÁREA 1 $(\mathbf{g} / \mathbf{K g})$} & \multicolumn{4}{c}{ ÁREA 2 $(\mathbf{g} / \mathbf{K g})$} \\
\hline Profundidades & $\mathbf{P}_{\mathbf{1}}$ & $\mathbf{P}_{\mathbf{2}}$ & $\mathbf{P}_{\mathbf{3}}$ & $\mathbf{P}_{\mathbf{4}}$ & $\mathbf{P}_{\mathbf{1}}$ & $\mathbf{P}_{\mathbf{2}}$ & $\mathbf{P}_{\mathbf{3}}$ & $\mathbf{P}_{\mathbf{4}}$ \\
\hline $0-10 \mathrm{~cm}$ & 0.43 & 0.48 & 0.81 & 0.65 & 0.40 & 0.63 & 0.53 & 0.68 \\
\hline $10-20 \mathrm{~cm}$ & 0.28 & 0.48 & 0.58 & 0.53 & 0.33 & 0.30 & 0.60 & 0.28 \\
$20-40 \mathrm{~cm}$ & 0.30 & 0.25 & 0.33 & 0.40 & 0.18 & 0.40 & 0.55 & 0.40 \\
\hline
\end{tabular}

Fonte: autores (2015)

No que diz respeito ao teor de $\mathrm{N}_{\text {Total }}$ relacionado à classe textural, o presente estudo mostrou que a maior concentração foi no tipo argiloso $(0,57 \mathrm{~g} / \mathrm{Kg})$, seguida pelo argilo arenoso $(0,5 \mathrm{~g} / \mathrm{Kg})$, e em último lugar a classe franco siltoso $(0,25 \mathrm{~g} / \mathrm{Kg})$, isso por parcela, entre as áreas 1 e 2 (Figura 27).

Figura 27 - Médias obtidas para o nitrogênio total nas duas áreas entre as parcelas e profundidades. Marabá PA.

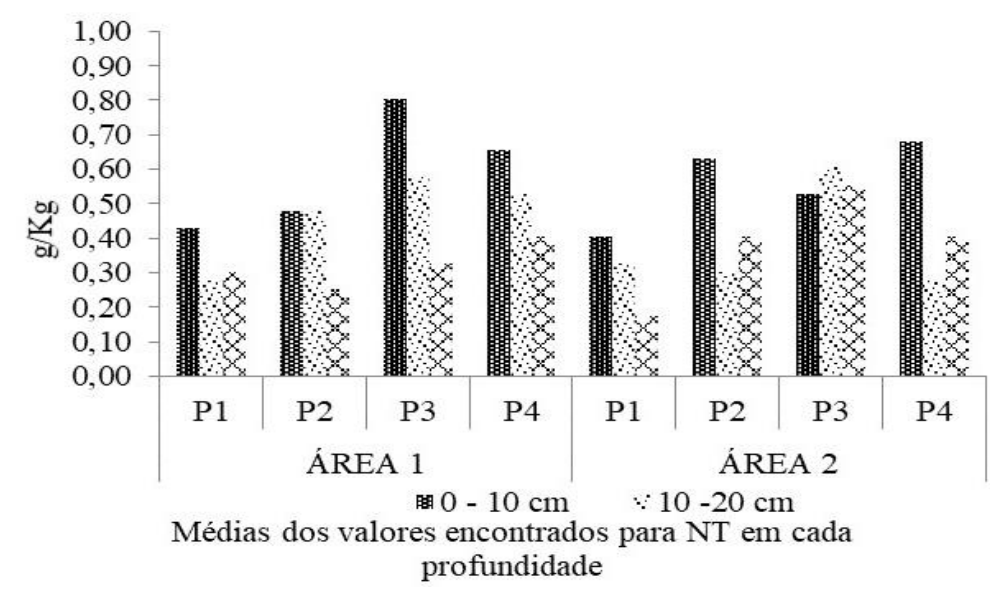

Fonte: autores (2015)

Após a análise dos dados verificou-se que a tendência de variações nos valores do teor de nitrogênio, principalmente entre as profundidades, verifica-se maiores concentrações na profundidade superior em todas as parcelas. Acerca dessa variação, foi efetuado um estudo por Longo e Espíndola (2000), em Latossolo amazônico e áreas de cerrado, todos de textura argiloso. Os pesquisadores concluiram que os teores de $\mathrm{N}_{\text {total }}$ se encontravam estocados nos primeiros $20 \mathrm{~cm}$ do solo, em razão provavelmente do acúmulo de matéria orgânica nos horizontes superficiais.

Também foi verificado que houve maior concentração de nitrogênio total foi verificada na camada $0-10 \mathrm{~cm}$ tanto em $\mathrm{A}_{1}(0,59 \mathrm{~g} / \mathrm{Kg})$ quanto em $\mathrm{A}_{2}(0,56 \mathrm{~g} / \mathrm{Kg})$. Estes valores foram obtidos a partir da média para cada profundidade. Assim, pode-se considerar que esta maior concentração de nitrogênio nessa profundidade, seja resultante da concentração de material orgânico e que esteja sob mineralização.

Para a relação carbono/nitrogênio $(\mathrm{C} / \mathrm{N})$, os dados obtidos e analisados indicaram tendências de variações para o valor médio em profundidades diferentes tanto em $\mathrm{A}_{1}$ quanto em $\mathrm{A}_{2}$ (Tabela 7).

Tabela 7 - Valores das médias obtidas para a relação C/N das duas áreas, em cada parcela e profundidade. Marabá PA.

\begin{tabular}{lcccccccc}
\hline & \multicolumn{3}{c}{ ÁREA 1 (g/Kg) } & \multicolumn{3}{c}{ ÁREA 2 (g/Kg) } \\
\hline Profundidades & $\mathbf{P}_{\mathbf{1}}$ & \multicolumn{1}{c}{$\mathbf{P}_{\mathbf{2}}$} & $\mathbf{P}_{\mathbf{3}}$ & $\mathbf{P}_{\mathbf{4}}$ & $\mathbf{P}_{\mathbf{1}}$ & $\mathbf{P}_{\mathbf{2}}$ & $\mathbf{P}_{\mathbf{3}}$ & $\mathbf{P}_{\mathbf{4}}$ \\
\hline $0-10 \mathrm{~cm}$ & 11.69 & 13.74 & 26.25 & 29.38 & 22.09 & 17.36 & 27.06 & 17.50 \\
$10-20 \mathrm{~cm}$ & 19.41 & 9.13 & 22.40 & 21.82 & 40.99 & 39.38 & 15.51 & 59.82 \\
\hline
\end{tabular}




\begin{tabular}{lllllllll}
\hline $20-40 \mathrm{~cm}$ & 14.95 & 35.09 & 20.41 & 25.92 & 75.37 & 15.82 & 21.33 & 33.55 \\
\hline
\end{tabular}

Fonte: autores (2015)

Quanto a relação $\mathrm{C} / \mathrm{N}$, independente da classificação textura, os estudos efetuados por Machado (2001) e Silva (2003), concluiram que, em geral, independentemente do tipo de solo ou de sua classificação textural, relações de $\mathrm{C} / \mathrm{N}$ que apresentarem baixo valor (em torno de $10 \mathrm{~g} / \mathrm{kg}$ ) indicam avançado estágio de decomposição de $\mathrm{MO}$, e valores altos (em torno de $30 \mathrm{~g} / \mathrm{kg}$ ) indicam baixa atividades microbianas.

Em Marabá, os dados obtidos e analisados indicaram que, a partir da média geral em cada área, ou seja, independente de parcela e profundidade, na área 1 (média dos valores da relação $\mathrm{C} / \mathrm{N}$ foi 20,85) está em estágio de baixo atividade microbiana, e consequentemente apresenta baixo teor de carbono e alto teor de nitrogênio. A área 2, onde a média dos valores encontrados foi 32,15 está em avançado estágio de decomposição da MO, consequentemente apresenta alto teor de carbono e atividade microbiana acelerada (Figura 28).

Figura 28 - Médias obtidas para a relação C/N nas duas áreas entre as parcelas e profundidades analisadas.

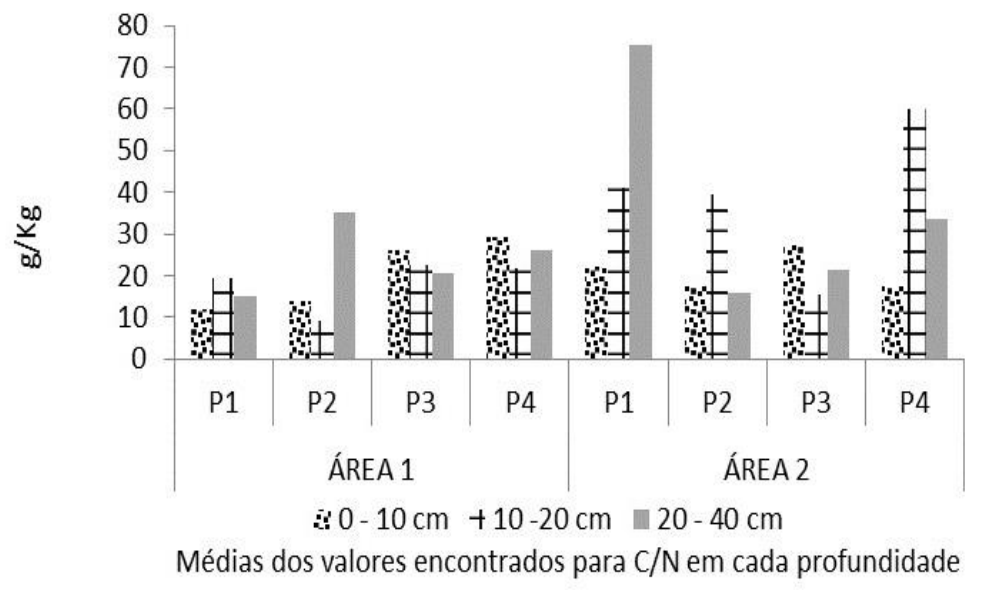

Fonte: autores (2015)

Os dados também indicaram que, em termos de profundidades, na área 1, já classificada com baixa atividade microbiana, apresentou comportamento diferenciado, ou seja, estágio avançado de decomposição da $\mathrm{MO}$ nas profundidades $20-40 \mathrm{~cm}\left(\mathrm{P}_{2}\right)$ e $0-10 \mathrm{~cm}\left(\mathrm{P}_{4}\right)$. Ainda é possível observar que existem parcelas em que algumas profundidades mostram valor bem próximo ao 30 (como $\mathrm{P}_{3} \mathrm{e}$ $\mathrm{P}_{4}$ ), destacando-as com atividade microbiana maior do que nas parcelas 1 e 2 . A área 2, já considerada como área de avançado estágio de decomposição da $\mathrm{MO}$, apresentou comportamento diferenciado, ou seja, valor menor que 30 , nas profundidades $0-10 \mathrm{~cm}\left(\mathrm{em} \mathrm{P}_{1}, \mathrm{P}_{2}, \mathrm{P}_{3}\right.$ e $\left.\mathrm{P}_{4}\right) ; 10-20 \mathrm{~cm}\left(\mathrm{em} \mathrm{P}_{3}\right)$, e 20$40 \mathrm{~cm}$ apenas em $\mathrm{P}_{3}$.

Consequentemente, esta relação apresenta-se bastante diversificada entre as profundidades, à medida que, em algumas parcelas, houve uma diminuição no sentido para as camadas inferiores e, em outros, houve um aumento na relação $\mathrm{C} / \mathrm{N}$. Sobre isso pode-se explicar que, onde os valores desta relação apresentaram crescimento, no sentido das profundidades, significa dizer que o nitrogênio está diminuindo em maior nível do que o acontece com o carbono, considerando que este também diminui sua concentração nas últimas camadas.

Quando os valores da relação $\mathrm{C} / \mathrm{N}$ diminuem em função do aumento das profundidades, ou seja, uma situação inversa significa dizer que o nitrogênio está diminuindo em menor quantidade do que o carbono, já que nenhum desses parâmetros apresentou concentração constante nas profundidades. Na relação entre as classes texturais encontradas em cada área, observou-se que na área 1 , a maior concentração de $\mathrm{C} / \mathrm{N}$ foi na classe franco siltoso $(24,59)$ seguida pelo argiloso $(23,87)$ e em terceiro lugar muito argiloso. A classe que apresentou menor concentração foi argilo arenoso 
(7,98). Já A2 apresentou um comportamento diferente, onde a maior concentração para a relação C/N foi encontrada na classe argiloso (33.08) e em segundo lugar franco argiloso $(21,93)$.

Finamente, observou-se que, em diferentes profundidades, na avaliação da fertilidade (carbono orgânico, matéria orgânica, relação carbono nitrogênio e nitrogênio), os valores apresentam tendências de variação nas concentrações entre as profundidades nas duas áreas (Figura 29)

Figura 29 - Médias obtidas para o carbono, matéria orgânica, relação C/N e nitrogênio total, nas duas áreas

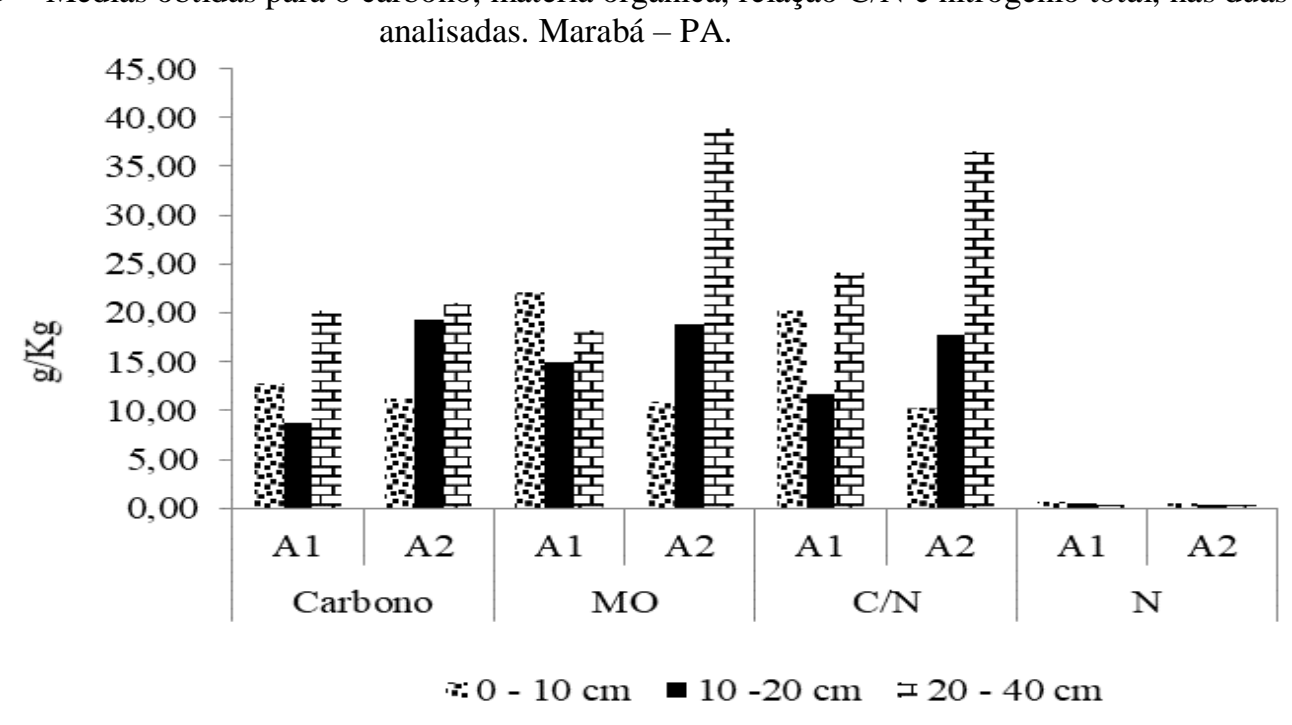

Médias dos valores para Corg, MO, C/N e NT nas profundidades

Fonte: autores (2015)

Os dados obtidos indicaram que houve tendência de elevação dos valores de Corg., maiores e mais próximos entre si, na área 2, sendo que os valores máximos ocorreram nas profundidades de 10 - $20 \mathrm{~cm}$ e $20-40 \mathrm{~cm}$. Na área 2 a matéria orgânica também apresentou um comportamento diferenciado, com base na média geral de cada área, do que era esperado (maior quantidade nos horizontes superficiais), no qual sua maior concentração foi encontrada na última camada analisada. Para esses dois casos, a possibilidade do solo alóctone ser removido apenas na parte superficial de uma região, para ser inserido na área de estudo. Nesse caso, mesmo a última camada daquela área pode apresentar solo da camada superior de onde o mesmo foi removido.

Na pesquisa realizada por Oliveira (2009), sobre indicadores da qualidade do solo no nordeste paraense, sob diferentes sistemas de cultivo, esse autor concluiu que as maiores concentrações de carbono orgânico estão relacionas a alta decomposição da matéria orgânica por microorganismos aeróbicos, os quais consomem nitrogênio neste processo. Na pesquisa realizada em Marabá, os teores de carbono orgânico, matéria orgânica e nitrogênio total são mais elevados na camada situada entre $20-40 \mathrm{~cm}\left(\mathrm{~A}_{2}\right)$, isso em face a alta decomposição da matéria orgânica por microorganismos aeróbicos, onde há o consumo do nitrogênio.

Quanto a distribuição da matéria orgânica no solo, Tongnon, Dematté, J. L e Dematté, J.A (2002), efetuaram estudo em Latossolos da Floresta Amazônica e dos Cerrados do Brasil Central, e concluiram que, à medida que aumenta o teor de argila do solo, aumenta o teor de matéria orgânica e, nesse caso, os solos da região amazônica apresentam elevado teor de nitrogênio com relações $\mathrm{C} / \mathrm{N}$ inferiores quando comparados com as concentrações encontradas nos solos de Cerrados. Na pesquisa realizada em Marabá, Os dados obtidos e analisados estão de acordo com o que foi observado pelo referido autor, ainda que no sentido oposto, visto que as duas áreas apresentaram baixos teores de nitrogênio $\left(0,46 \mathrm{~g} / \mathrm{Kg}\right.$ em $\mathrm{A}_{1}$ e $0,44 \mathrm{~g} / \mathrm{Kg}$ em $\left.\mathrm{A}_{2}\right)$, em contrapartida apresentaram altas concentrações de $\mathrm{C} / \mathrm{N}\left(20,85 \mathrm{~g} / \mathrm{Kg}\right.$ em $\mathrm{A}_{1}$, e $32,15 \mathrm{~g} / \mathrm{Kg}$ em $\left.\mathrm{A}_{2}\right)$.

$\mathrm{Na}$ análise dos dados obtidos, também se observou que, em geral, $\mathrm{A}_{1}$ apresentou valores mais equilibrados, sem grandes variações, em todos os parâmetros, entre as profundidades. Isso significa 
que a concentração desses atributos está disposta de forma mais uniforme, mesmo que não o suficiente, em toda a profundidade analisada.

Sobre esse equilíbrio e uniformidade na relação $\mathrm{C} / \mathrm{N}$, foi realizada uma pesquisa acerca da fertilidade do solo em sistemas de plantio direto, por Lopes et al. (s/d), e esses autores indicaram que a alteração no teor de matéria orgânica, tanto em quantidade como em qualidade, tem implicações graduais nas alterações do $\mathrm{pH}$, na dinâmica de nitrogênio e de outros nutrientes, Eles afirmam também que isso demonstra um aumento no teor de matéria orgânica, está ocorrendo armazenamento de $\mathrm{N}$ no solo.

Na pesquisa ocorrida em Marabá, os valores obtidos para as médias dos teores de $\mathrm{N}$ e MO, indicaram que o teor desses dois atributos é maior nas camadas superficiais do solo, e que apesar da concentração de MO estar medianamente alta, a concentração de nitrogênio no solo é muito baixa. Isso mostra que não está ocorrendo armazenamento de $\mathrm{N}$ no solo, que provavelmente deve estar sendo consumido pelos microorganismos aeróbicos no processo de decomposição da matéria orgânica.

\section{ACIDEZES $((\mathrm{H}++$ AL+3); CÁTIONS TROCÁ VEIS; CAPACIDADE DE TROCA CATIÔNICA (CTC); SOMA DE BASES (S); PERCENTAGEM DE SATURAÇÃO DE BASES (V)}

Os dados obtidos e analisados para a acidez potencial $\left(\mathrm{H}^{+}+\mathrm{Al}^{+3}\right)$, cátions trocáveis, CTC, soma de bases não indicaram tendências a variações quando relacionados entre si, nas duas áreas, nas mesmas profundidades (Tabela 08).

Tabela 8 - Valores médios encontrados para acidez potencial $\left(\mathrm{H}^{+}+\mathrm{Al}^{+3}\right)$, cátions trocáveis, CTC, soma de bases e percentagem de saturação de bases nas duas áreas, em cada profundidade.

\section{ÁREA 1}

ÁREA 2

\begin{tabular}{lcccccc}
\hline \multicolumn{7}{c}{ PROFUNDIDADADES } \\
\hline $\begin{array}{l}\text { Elementos } \\
\text { (cmolc/kg) }\end{array}$ & $\mathbf{0 - 1 0} \mathbf{~ c m}$ & $\mathbf{1 0} \mathbf{- 2 0} \mathbf{~ c m ~}$ & $\mathbf{2 0} \mathbf{- 4 0} \mathbf{~ c m}$ & $\mathbf{0}-\mathbf{1 0} \mathbf{~ c m}$ & $\mathbf{1 0} \mathbf{- 2 0} \mathbf{~ c m}$ & $\mathbf{2 0}-\mathbf{4 0} \mathbf{~ c m ~}$ \\
\hline $\mathbf{A l + 3}$ & 0.42 & 0.26 & 1.48 & 0.53 & 0.77 & 1.02 \\
\hline $\mathbf{H}^{+}+\mathbf{A l}^{+\mathbf{3}}$ & 0.42 & 0.52 & 0.98 & 1.00 & 1.33 & 1.53 \\
\hline $\mathbf{C a}$ & 5.78 & 3.90 & 3.00 & 7.60 & 7.60 & 5.28 \\
\hline $\mathbf{M g}$ & 1.73 & 1.43 & 2.16 & 2.44 & 1.61 & 1.14 \\
\hline $\mathbf{N a}$ & 0.98 & 0.84 & 0.63 & 0.69 & 0.58 & 0.55 \\
\hline $\mathbf{K}$ & 1.07 & 0.95 & 0.64 & 0.55 & 0.44 & 0.55 \\
\hline $\mathbf{C T C}$ & 13.01 & 10.77 & 11.81 & 12.74 & 12.28 & 9.51 \\
\hline $\mathbf{S}$ & 11.28 & 8.94 & 9.12 & 12.01 & 11.25 & 8.51 \\
\hline $\mathbf{V}(\boldsymbol{\%})$ & 87.07 & 82.55 & 77.9 & 93.98 & 88.98 & 88.67 \\
\hline
\end{tabular}

Fonte: autores (2015)

Em relação ao pH, no estudo efetuado por Oliveira (2009), foi concluído que a mineralização da matéria orgânica libera cátions nas camadas do solo, em especial cátions H+, o que provoca redução no $\mathrm{pH}$. Nos solos analisados em Marabá, os valores das médias para o teor de acidez não foram elevados, principalmente na $\mathrm{A}_{1}$. Em $\mathrm{A}_{2}$, ocorreram os maiores índices de acidez, e isso difere daquela conclusão relatada por Oliveira (2009), isso porque houve maior valor para o $\mathrm{pH}$ e MO. Sobre isso, embora a acidez esteja elevada, em comparação com A1, supõe-se que nesse sistema a mineralização da matéria orgânica ainda seja atuante.

Quanto ao teor de alumínio trocável $\left(\mathbf{A l}^{+3}\right)$, entre as duas áreas não apresentou tendências de variações significativas quanto aos valores médios, quando relacionas entre si, com profundidade em comum. Mas, quando relacionas isoladamente cada área, observou-se que $A_{1}$, apresentou variações mais significativas em dois grupos de profundidades: $(0-10$ com $20-40 \mathrm{~cm}$; significância <0.05) e, (10-20 com 20-40cm; significância <0.01). Já $A_{2}$, mesmo relacionando entre si, nas profundidades, os valores de alumínio trocável não apresentaram significância. 
Em relação aos valores determinados para o teor de alumínio trocável, houve tendência de variações entre $0,11 \mathrm{cmolc} / \mathrm{kg}$ a $2,74 \mathrm{cmolc} / \mathrm{kg}$. Em relação ao aumento da profundidade nos solos analisados, ocorreram variações médias nos teores, para mais ou para menos no teor de alumínio trocável. Nas duas áreas, a maior concentração encontrada foi na profundidade $20-40 \mathrm{~cm}$.

Em um estudo efetuado em Latossolo Amarelo distrófico e Argissolos Amarelo distrófico, por Souza et al. (2010), os autores concluiram que o teor de alumínio trocável apresentou tendência a elevação de acordo com o aumento da profundidade. Em comparação com os dados obtidos em Marabá, verificou-se que, $A_{2}$, apresentou o mesmo comportamento observado por Souza et al. (2010). Sobre isso supõe-se que pode ter havido processo de lixiviação na área, o que carreou o alumínio para as camadas inferiores.

$\mathrm{Na}$ área 1, dados obtidos não mostraram um aumento no teor de alumínio com o aumento da profundidade, principalmente quando observada a camada intermediária $(10-20 \mathrm{~cm})$. Nesse caso e para essa profundidade, é possível que a mineralização da matéria orgânica não tenha atuado no aumento do teor de alumínio.

A área 2 apresentou teores mais elevados de $\mathrm{Al}^{+3}$ em todas as profundidades em comparação com $\mathrm{A}_{1}$. Acerca desses teores elevados, Belizário (2008), Castro (2008), Correia e Andrade (2008 e Silva (2003), realizaram pesquisas sobre a alta concentração de MO melhora a ciclagem dos nutrientes devido à atividade bacteriana que, além da liberação desses nutrientes no solo, pode também ter liberado o alumínio que estava armazenado na MO. Em Marabá, na maioria das parcelas e profundidades, os valores encontrados foram superiores em $A_{2}$ quando comparado com $A_{1}$, o que corrobora com o exposto pelos pesquisadores. Já para Pereira Júnior (2011), a explicação dos teores elevados de alumínio trocável é antrópica. Como os solos analisados em Marabá, foram bastante antropizados pelo soerguimento da ponte em concreto, isso elevou os teores de alumínio em $\mathrm{A}_{1}$ e $\mathrm{A}_{2}$, sendo que, neste, os teores foram mais elevados em relação à $\mathrm{A}_{1}$

Para os teores de cálcio $(\mathrm{Ca})$, magnésio $(\mathrm{Mg})$, os dados analisados indicaram que há uma tendência de maiores concentrações na $\mathrm{A}_{2}$, principalmente nas camadas superiores, até $20 \mathrm{~cm}$, enquanto que o teor de sódio $(\mathrm{Na})$ e potássio $(\mathrm{K})$ apresentou maiores valores na $\mathrm{A}_{1}$, também nas primeiras profundidades. Estudo realizado em Latossolo Amarelo por Pereira et al. (2000), concluiu que o os teores de cálcio no período seco sempre foram mais elevados apresentando-se com diferenças estatísticas significativas. Concluiram também que isso pode ter resultado da mineralização da matéria orgânica que é mais acentuada nesse período. Apesar de a sazonalidade não ser objeto do presente trabalho, o município de marabá apresenta estações mais secas e de baixo índice de pluviosidade, que ocorrem justamente no período em que as amostras foram coletadas. Portanto este pode ser um fator que influenciou o alto teor de $\mathrm{Ca}$ encontrado nas duas áreas.

Outro estudo efetuado por Luizão (2007) sobre a ciclagem de nutrientes em florestas tropicais mostrou que ocorre aumento no teor de potássio e magnésio é devido o enriquecimento provocado pela lavagem das copas das árvores que produzem fluxos de magnésio, e principalmente de potássio. Já em Marabá, as duas áreas em estudo não apresentavam vegetação arbustiva, portanto os teores desses macronutrientes não estão relacionados à lavagem das copas das árvores como ocorreu no referido estudo. Estes macronutrientes podem ter influência pelo teor de MO, ou ainda, já estarem presentes no solo que foi introduzido na área.

Os valores das médias da soma de bases não apresentaram efeito estatístico significativo quando relacionadas cada área individualmente entre as profundidades, nem quando relacionadas entre si. Verificou-se também que, em geral, apesar da profundidade 20 - $40 \mathrm{~cm}$ na $\mathrm{A}_{1}$ apresentar-se como exceção, há uma tendência de diminuição dos valores da soma de bases de acordo com o aumento da profundidade. Isso pode estar relacionado à diminuição do teor de matéria orgânica em relação ao aumento da profundidade, para os casos em que esse comportamento se aplica.

$O$ maior valor da soma de bases foi encontrado na $A_{2}$, profundidade $0-10 \mathrm{~cm}$, ainda assim a diferença deste valor para o máximo encontrado na $\mathrm{A}_{1}$ não é muito grande. Estudo realizado em Latossolo Amarelo no nordeste paraense, por Silva et al. (2006), concluiram que esse tipo de solo apresentou acidez elevada resultante da neutralização por cátions básicos. Com base nesses resultados 
e pode-se associar os maiores valores encontrados para a soma de bases estão relacionados com a diminuição da acidez, que apresentou valores mínimos nas profundidades em que o valor de $\mathrm{S}$ se mostrou elevado.

Quanto à capacidade de trocas de cátions (CTC) os resultados obtidos apresentaram significância em todas as profundidades, quando relacionou-se cada área individualmente, no entanto, o inverso ocorreu quando relacionou-se as duas áreas entre profundidades. $\mathrm{O}$ maior valor de media para CTC ocorreu na profundidade $10-20 \mathrm{~cm}$ na $A_{1}$, e, os maiores teores concentraram-se nas camadas superiores. Observou-se também que foram pequenas as variações entre os valores, para mais ou para menos, em todas as profundidades, o que significa que os valores estão próximos ao equilíbrio.

Relacionando a matéria orgânica com a classificação textural, e considerando que quanto maior o teor de argila, maior será a concentração de MO e, maior será a reação da CTC o que favorece a fertilidade do solo porque poderá ocorrer maior absorção de nutrientes catiônicos pelas plantas (LOPES et al., s/d). Os valores encontrados neste estudo, principalmente na $A_{1}$ comprovam esta teoria, já que os valores de reação da CTC (Figura 30) foram maiores na classe argiloso (22,91 $\mathrm{cmolc} / \mathrm{kg}$ ), seguida pela muito argiloso $(13,5 \mathrm{cmolc} / \mathrm{kg})$. $\mathrm{O}$ menor valor foi encontrado na franco argiloso $(5,54 \mathrm{cmolc} / \mathrm{kg})$. O contrário desta situação ocorreu na $\mathrm{A}_{2}$, onde a maior concentração foi na franco argiloso $(23,19 \mathrm{cmolc} / \mathrm{kg})$ e o menor na argiloso $(18,22 \mathrm{cmolc} / \mathrm{kg})$.

Em um estudo efetuado em Latossolo Amarelo, de textura média, por Pereira et al. (2000), concluiu que as concentrações de CTC, revelou que a deposição de matéria orgânica no solo provoca aumento na CTC, e promove uma melhor adsorção de cátions trocáveis liberados pela decomposição da matéria orgânica. Na pesquisa realizada em Maraba, os valores encontrados para a CTC, indicaram que, nas camadas mais superficiais, principalmente $0-10 \mathrm{~cm}$, nas duas áreas foram elevados quando comparados com as demais profundidades. A possível explicação para esses resultados é a deposição de matéria orgânica sobre a superfície do solo o que provocou aumento na CTC nesses sistemas.

A percentagem de saturação de bases (V) não apresentou efeito estatístico significativo, quando comparadas as áreas individualmente. No entanto, quando foi feita a relação entre as duas áreas, as profundidades $20-40$ (A1) e, $10-20$ (A2) apresentaram efeito estatisticamente significativo (<0.01). Sobre os solos eutróficos, Silva (2003), efetuou estudo sobre saturação de bases, os valores para esse quesito equivalem a $\mathrm{V} \%>50 \%$, o que mostra uma riqueza em nutrientes, enquanto que solo com V\%<50\% representam solos distróficos, com pouco nutrientes. Nesse caso em Marabá, de acordo com os percentuais obtidos nas duas áreas, pode-se afirmar que por unanimidade as duas áreas classificam-se por apresentarem solos eutróficos, já que o menor valor de V\% foi 77,9\%.

\section{CONCLUSÃO}

A obra de duplicação da Ponte Rio Itacaiúnas provocou alterações nas características físicas químicas e biológicas do solo, em todas as extensões de suas atividades, seja instalação do canteiro de obas, da central de concreto, dentre outras. A introdução de material alóctone utilizado para manter a estabilidade do terreno, pode ter sido o principal fator que alterou os parâmetros analisados como o pH por exemplo e, modificou o comportamento de outros como a matéria orgânica. Este material além de provavelmente não apresentar características comuns do solo natural da área, deve ter sido removido apenas em sua parte superficial, fator que deve ter influenciado os resultados encontrados nas profundidades estudadas.

A área 1 já está em fase de regeneração, principalmente por estar localizada na faixa da ponte antiga, ou seja, sofreu antropização a mais tempo. Já a área 2 estava mais próxima de onde havia sido instalada a central de concreto e, por isso está mais alterada, principalmente para o $\mathrm{pH}$. A fauna, apesar do grau elevado de antropização, está presente e representada pela ordem Hymenoptera, logo, é um indicativo que esta área pode estar recuperando a fertilidade do solo quanto as propriedades físicas e químicas alteradas por uso inadequado do solo. 
A fauna edáfica sofreu influência pela a oferta de material orgânico e nutriente, e, novamente, como ocorreu para os atributos do solo, a inserção de material alóctone, no que diz respeito ao forrageamento de organismos que podem não ter se adaptado ao novo meio ali inserido. Outros fatores ambientais como precipitação, umidade e temperatura também atuam sobre a fauna do solo podendo aumentar ou diminuir a densidade populacional e a diversidade de espécies comprometendo a fertilidade do solo. No entanto estes fatores não foram objetos deste estudo, e, portanto, ainda que seja de conhecimento, sua influência nos resultados não pode ser comprovada.

Apesar de constar nos documentos estudos a elaboração do PRAD pela empresa responsável pela obra, as ações efetuadas, no que diz respeito às medidas de correção dos impactos causados ao local, não foram suficientes para corrigir o impacto, visto que as alterações permanecem. Ficou evidente que a avaliação da qualidade do solo é fundamental na determinação da sustentabilidade e qualidade dos sistemas de manejo utilizados, principalmente no que diz respeito às áreas onde a atividade antrópica inadequada tem gerado sua degradação e inviabilização para usos futuros. Assim, é necessário que seja desenvolvida uma sensibilidade mais efetiva sobre o fator solo, a partir de um processo educativo que privilegie uma concepção de sustentabilidade na relação homem-natureza.

\section{REFERÊNCIAS}

ABNT. ASSOCIAÇÃO BRASILEIRA DE NORMAS TÉCNICAS. NBR 1367/91. Áreas de vivência em canteiro de obras. Disponível em: < http://www.iw8.com.br/downloads/abnt---nbr1367-e-nr-18---canteiro-de-obras---diretrizes.html>. Acesso em: 21 jul. 2013.

ALMEIDA, E. Lei 12.305 Política Nacional de Resíduos Sólidos. 2012. Cuiabá, MT. 2012. Disponível em: <http://www.jurisway.org.br/v2/dhall.asp?id_dh=7508>. Acesso em: 24 out. 2013.

ALMEIDA, J. J. A cidade de Marabá sob o impacto dos projetos governamentais. 2008. $273 \mathrm{f}$. Dissertação (Mestrado em História). Faculdade de Filosofia, Letras e Ciências Humanas. Universidade de São Paulo. São Paulo, SP. 2008.

ANDRADE, L. B. O uso da fauna edáfica como bioindicadora de modificações ambientais em áreas degradadas. 2000. Dissertação (Bacharelado em Ecologia). Universidade Federal Rural do Rio de Janeiro, Rio de Janeiro, 2000.

ARAÚJO, A. S. F. A qualidade do solo. Informativo Científico da FAPEPI. n. 4. Teresina, Piauí. 2005. Disponível em: <http://www.fapepi.pi.gov.br/novafapepi/sapiencia4/artigos1.php>. Acesso em: 17 out. 2013.

ARAÚJO, A. S. F; MONTEIRO, R, T. R. Indicadores da qualidade do solo. Uberlândia - MG: Journal Bioscience, v. 23, n.3, p. $66-75,2007$.

ARAÚJO, E. A. et al. Qualidade do solo: conceitos e indicadores de avaliação. 2012. Revista Brasileira de Tecnologia Aplicada nas Ciências Agrárias. v.5, n.1, p.187-206. 2012.

ARAÚJO, R. et al. Qualidade de um solo sob diferentes usos e sob cerrado nativo. 2007. Revista Brasileira de Ciência do Solo. 2007.

AQUINO, A. M. et al. Amostragem da mesofauna edáfica utilizando funis de Berlese-Tüllgren modificado. EMBRAPA, 2006a. (Circular técnica 17). 
AQUINO, A. M. et al. Recomendações para coleta de artrópodes terrestres por armadilhas de queda (pitfall-traps). Seropédica - RJ: Empresa Brasileira de Pesquisa Agropecuária, 2006b. (Circular Técnica 18).

AQUINO, A. M; CORREIA, M. D. F. Invertebrados edáficos e o seu papel nos processos do solo. Embrapa Agrobiologia. 2005. (Documentos, 201),

AQUINO, Adriana Maria. Fauna do solo e sua inserção na regulação funcional do agroecossistemas. In: AQUINO, A. M.; ASSIS, R. L. (Ed.). Processos Biológicos no sistema solo-planta: ferramentas para uma agricultura sustentável. Brasília, Embrapa Agrobiologia. p. 47-75. 2005.

AYRES, M. et al. BioEstat - Aplicações estatísticas nas áreas das ciências biomédicas. 2007. Manual para Usuário. Instituto de Desenvolvimento Sustentável de Mamirauá. Belém, Pará, 2007. Disponível em: <http://euler.mat.ufrgs.br/ giacomo/Manuais-softw/BIOESTAT/ManualBioEstat.pdf >. Acesso em: 21 jul. 2013.

BALDIN JUNIOR, P. R. Levantamento da herpetofauna de serrapilheira em remanescente florestal na Faculdade Assis Gurgacz, Cascavel - Paraná. s/d. Faculdade Assis Gurgacz. Cascavel, PR. s/d. Disponível em: <http://www.fag.edu.br/tcc/2007/Ciencias_Biologicas_Bacharelado/Levantamento_da_herpetofaun a_de_serrapilheira_em_remanescente_florestal_na_Faculdade_Assis_Gurgacz.pdf $>$. Acesso em 25 out. 2013.

BARETTA, D. Fauna do solo e outros atributos edáficos como indicadores da qualidade ambiental em áreas com Araucaria angustifolia no Estado de São Paulo. 2007. Tese (Doutorado em Solos e Nutrição de Plantas) - Escola Superior de Agricultura Luiz de Queiroz, Universidade de São Paulo, Piracicaba, 2007.

BARETTA, D. et al. Colêmbolos (Hexapoda: Collembola) como bioindicadores de qualidade do solo em áreas com Araucaria angustifólia. Revista Brasileira de Ciência do Solo. v. 32, p. 2699. 2007.

BARRIOS, E.; COUTINHO, H. L. C.; MEDEIROS, C. A. B. InPac-S: Integração participativa de conhecimentos sobre indicadores de qualidade do solo. 2011. Guia Metodológico. World Agrofloresty Centre (ICRAF), Embrapa, CIAT. Nairobi. 2011.

BASTOS, D. C. O. Teoria - pH, reação do solo e calagem. 2008. Notas de aula. Faculdade da Amazônia (IESA). Disponível em: <http://pt.scribd.com/doc/2434905/Teoria-pH-reacao-do-solo-ecalagem>. Acesso em 19 nov. 2013.

BELIZÁRIO, M. H. Mudança no estoque de carbono do solo devido ao uso agrícola da terra no Sudoeste da Amazônia. 2008. Dissertação (Mestrado em Solos e Nutrição de Plantas) - Escola Superior de Agricultura Luiz de Queiroz, Universidade de São Paulo, Piracicaba, 2008.

BERTINI, S. C. B. Indicadores microbiológicos de qualidade do solo em Florestas de Araucária no Estado de São Paulo. 2010. Tese (Doutorado em Microbiologia Agrícola) - Escola Superior de Agricultura Luiz de Queiroz, Universidade de São Paulo. Piracicaba, 2010.

BRASIL. Lei 6.938, de 31 de agosto de 1981. Disponível em: <http://www.planalto.gov.br/ccivil_03/leis/16938.htm>. Acesso em: 21 jul. 2013. 
BRASIL. Congresso. Senado. Resolução Conama n. 001, de 23 de janeiro de 1986. Disponível em: <http://www.mma.gov.br/port/conama/res/res86/res0186.html>. Acesso em: 20 jul. 2013.

BRASIL. Congresso. Senado. Resolução Conama n. 237, de 23 de janeiro de 1997. Disponível em: <http://www.mma.gov.br/port/conama/res/res97/res23797.html>. Acesso em: 20 set. 2013.

BRASIL. Lei 9.605, de 12 de fevereiro de 1998. Disponível em: < http://www.planalto.gov.br/ccivil_03/leis/19605.htm>. Acesso em: 19 out. 2013.

BRASIL. Congresso. Senado. Resolução Conama n. 307, de 05 de julho de 2002. Disponível em: <http://www.mma.gov.br/port/conama/legiabre.cfm?codlegi=307>. Acesso em: 20 jul. 2013.

CARELI, E. D. A Resolução CONAMA No $301 / 2002$ e as novas condições para gestão dos resíduos de construção e demolição. 2008. Dissertação (Mestrado em Tecnologia) - Centro Estadual de Educação Tecnológica Paula Souza. São Paulo, SP. 2008.

CARVALHO, E. J. M.; FIGUEIREDO, M.S.; COSTA, L. M. Comportamento físico-hídrico de um podzólico vermelho-amarelo câmbico fase terraço sob diferentes sistemas de manejo. Pesq. Agropec. Bras. v.34, n.2, p. 257-265.1999.

CARVALHO, J. E. B. et al. Efeito de sistemas de manejo nos indicadores químicos de qualidade do solo. 2007. Disponível em: <http://www.infobibos.com/Artigos/2007_2/Indicadores/index.htm>. Acesso em: 17 out. 2013.

CASALINHO, H. D. et al. Qualidade do solo como indicador de sustentabilidade de agroecossistemas. Revista Brasileira de Agro ciência, v. 13, n. 2, p. 195-203. 2007.

CASTRO, G. C. Carbono orgânico nas frações granulométricas e húmicas em solos de diferentes texturas sob floresta da região noroeste mato-grossense, 2008. Dissertação (Mestrado em Ciências Florestais em Ambientais). Universidade Federal de Mato Grosso, 2008.

CMT ENGENHARIA. Plano de Controle Ambiental - Canteiro de obras para a construção da ponte sobre o rio Itacaiúnas. s/d. 30 f. Marabá, Pará.

CMT ENGENHARIA. Plano de gerenciamento de resíduos sólidos - Obras da ponte sobre o rio Itacaiúnas, Marabá-PA. Canteiro de obras. s/d. Marabá, Pará.

CONCEICÃO, P. C. et al. Qualidade do solo em sistemas de manejo avaliada pela dinâmica da matéria orgânica e atributos relacionados. Rev. Bras. Ciênc. Solo, Viçosa, v. 29, n. 5. 2005.

COPOLA, R. A Política Nacional de Resíduos Sólidos. Lei Federal No 12.305, de 2 de agosto de 2010). 2011. Disponível em: <http://www.acopesp.org.br/artigos/Dra.\%20Gina\%20Copola/gina\%20artigo\%2067.pdf>. Acesso em 21 out. 2013.

CORDEIRO, F. C. et al. Diversidade da macrofauna invertebrada do solo como indicadora da qualidade do solo em sistema de manejo orgânico de produção. Seropédica, RJ. Revista Universidade Rural: Série Ciências da Vida, v. 24, n.2, p. 29-34. 2004.

CORREIA M. E. F., OLIVEIRA L. C. M. Fauna de solo: aspectos gerais e metodológicos. Embrapa Agrobiologia. 2000. (Documentos, 112). 
CORREIA, M. E. F. Relações entre a diversidade da sauna do solo e o processo de decomposição e seus reflexos sobre a estabilidade dos ecossistemas. Seropédica: Embrapa Agrobiologia. 2002. (Documentos, 156).

CORREIA, Maria. E. F.; ANDRADE, Aluísio. G. Formação de serrapilheira e ciclagem de nutrientes. In: SANTOS, G. A. et al. (Ed.). Fundamentos da Matéria Orgânica do sol: ecossistemas tropicais e subtropicais. 2 ed. Porto Alegre: Metrópole. 2008. p. 137-158. 2008.

CORREIA, M. E. F.; OLIVEIRA, L. C. M. de. Importância da fauna de solo para a ciclagem de nutrientes. 2006. Disponível em: < http://www.agencia.cnptia.embrapa.br/recursos/biotacap4IDQOAsuHeSsM.pdf>. Acesso em 22 out. 2013.

COSTA, E. R. Uma visão comentada sobre a Lei da PNRS. s/d. Revista Petrus. Disponível em: http://www.revistapetrus.com.br/uma-visao-comentada-sobre-a-lei-da-pnrs/. Acesso em 24 out. 2013.

D'ANDREA, A. F. et al. Atributos biológicos indicadores da qualidade do solo em sistemas de manejo na região do cerrado no sul do estado de Goiás. 2002. Revista Brasileira de Ciência do Solo. v, 26 n. 4. 2002.

DEMATTE, J. L. I.; DEMATTE, J. A. M. Comparações entre as propriedades químicas de solos das regiões da floresta amazônica e do cerrado do Brasil Central. Piracicaba, (SP). Scientia agrícola. v. 50, n. 2. 1993.

DEVIDE, A. C. P.; CASTRO, C. M. de. Manejo do solo e a dinâmica da fauna edáfica. 2008. Pesquisa \& Tecnologia, v. 5, n.2, 2008.

DNIT. DEPARTAMENTO NACIONAL DE INFRAESTRUTURA DE TRANSPORTES. Primeiro relatório semestral de atividades: Plano de Controle Ambiental. Duplicação da BR-230 perímetro urbano de Marabá, Pará. 2009. Marabá, Pará. 2009.

DUCATTI, F. Fauna edáfica em fragmentos florestais e em áreas reflorestadas com espécies da mata atlântica. 2002. Dissertação (Mestrado) - Escola Superior de Agricultura Luiz de Queiroz. Piracicaba, SP, 2002.

EMBRAPA. EMPRESA BRASILEIRA DE PESQUISA AGROPECUÁRIA. Propriedades físicas dos principais solos da Amazônia brasileira em condições naturais. 1982. Boletim de Pesquisa. Ministério da Agricultura. Belém, Pará. 1982.

FARIAS, T. Q. Aspectos gerais da política nacional do meio ambiente - comentários sobre a Lei no 6.938/81. 2006. Âmbito Jurídico, Rio Grande, IX, n. 35. 2006. Disponível em: $<$ http://www.ambito-

juridico.com.br/site/index.php?n_link=revista_artigos_leitura\&artigo_id=1544>. Acesso em: 21 out. 2013.

FEARNSIDE, P. M.; LEAL FILHO, N. Soil and development in Amazonia: Lessons from the Biological Dynamics of Forest Fragments Project. In: R.O. Bierregaard, C. Gascon, T.E. Lovejoy \& R. Mesquita (eds.). Lessons from Amazonia: The Ecology and Conservation of a Fragmented Forest. Yale University Press, New Haven, Connecticut, U.S.A. 2001. p. 291-312. 
FERREIRA, J. M. L. Indicadores de qualidade do solo e de sustentabilidade em cafeeiros arborizados. 2005. Dissertação (Mestrado em Agroecossistemas) - Centro de Ciências Agrárias, Universidade Federal de Santa Catarina. Florianópolis, SC. 2005.

FREITAS, M. P. Flutuação populacional de oligochaeta edáficos em hortas sob sistemas convencional e orgânico no município de Canoinhas/SC. 2007. Dissertação (Mestrado em Ciências) - Universidade Federal do Paraná, Curitiba, 2007.

GOMES, M. A. F.; FILIZOLA, H. F. Indicadores físicos e químicos de qualidade de solo de interesse agrícola. Empresa Brasileira de Pesquisa Agropecuária. Jaguariúna. 2006.

GOMES, A. S. Qualidade do solo: conceito, importância e indicadores da qualidade. s/d. Disponível em: <http://www.grupocultivar.com.br/site/content/artigos/artigos.php?id=447>. Acesso em 17 out. 2013.

HOLANDA, M. Princípios do Direito Ambiental, Lei 6.938/81. 2013. Disponível em: <http://www.euvoupassar.com.br/?go=artigos\&a=fXvZ2Etc6jvdj0vOYONj_BQovi1EyRcLXyRPD fekzHs >. Acesso em 21 out. 2013.

IBGE. INSTITUTO BRASILEIRO DE GEOGRAFIA E ESTATÍSTICA. Censo 2010. Disponível em:

<http://www.ibge.gov.br/cidadesat/painel/painel.php?codmun=150420>. Acesso em: 9 jun. 2013.

KIEHL, E. J. Manual de edafologia: Relações solo - planta. 1979. Escola Superior de Agricultura "Luiz de Queiroz". Universidade de São Paulo. Editora Agronômica CERES. Piracicaba, SP. 1979

KONRAD, O.; C, T. B. A preservação ambiental na visão da política nacional dos resíduos sólidos. In: Âmbito Jurídico, Rio Grande, XIV, n. 89, jun. 2011. Disponível em: <http://www.ambitojuridico.com.br/site/index.php?artigo_id=9750\&n_link=revista_artigos_leitura>. Acesso em 24 out. 2013.

LAVELLE, P. et al. Impact of soil fauna on the properties of soil in the Humid Tropics. In: LAL, R; SANCHES, P. A. Myths and Science of Soils of the Tropics. Madison - Viscont - USA: Soil Science Society of America and American Society of Agronomy, Chapter 9, p.157 - 185. 1992. Disponível em: < $\quad$ http://horizon.documentation.ird.fr/exldoc/pleins_textes/pleins_textes_6/b_fdi_33-34/38610.pdf>. Acesso em: 10 out. 2013.

LAVELLE, P. Faunal activities and soil processes: adaptative strategies that determinate ecosystem function. Advances in Ecological Research. v. 27. p.132. 1997.

LEITE, E. L.; LOBATO, A. C. N. Supressão da mata ciliar no entorno de duas nascentes no Rancho Nossa Senhora de Nazaré, Assentamento $1^{\circ}$ de Março, município de São João do Araguaia, Pará: sugestões para recuperação. 2012. Dissertação (Bacharel em Engenharia Ambiental) - Universidade do Estado do Pará, Marabá, 2012.

LIMA, S. S. et al. Diversidade da macrofauna edáfica em agroflorestais de diferentes estádios sucessionais. Revista Brasileira de Agroecologia, v. 2, n. 2, 2007.

LONGO, R. M.; ESPINDOLA, C. R. C - orgânico, NTotal e substâncias húmicas sob influência da introdução de pastagens (Brachiaria sp.) em áreas de cerrado e floresta Amazônica. Revista Brasileira de Ciência do Solo, n.24, p.723 - 729, 2000. 
LOPES, A. S. et al. Sistema plantio direto: bases para o manejo da fertilidade do solo. s/d. Associação Nacional para Difusão de Adubos. São Paulo, SP. s/d. Disponível em: <http://www.anda.org.br/multimidia/lt_spd.pdf>. Acesso em 19 nov. 2013.

LUIZÃO, F. J. Ciclos de nutrientes na Amazônia: respostas às mudanças ambientais e climáticas. São Paulo (SP). Revista Ciência e Cultura, v. 59, n.3, p. 31-36, 2007.

MACAMBIRA, M. L. J. Diversidade de Colêmbolos (Hexapoda: Collembola) na Estação Científica Ferreira Penna, Município de Melgaço, Pará. Belém-Pará: CZO_05. Estação científica Ferreira Penna - dez anos de Pesquisa na Amazônia. Belém-PA 2005.

MACEDO, L. P. M. Diversidade de formigas edáficas (Hymenoptera: Formicidae) em fragmentos da mata atlântica do estado de São Paulo. 2004. 126 f. Dissertação (Doutorado em Entomologia). Escola Superior de Agricultura Luiz de Queiroz, Universidade de São Paulo. Piracicaba, SP. 2004.

MACHADO, P. L. O. A. Manejo da matéria orgânica em solos tropicais. Rio de Janeiro - RJ: EMBRAPA, 2001. (Documento 24).

MARABÁ, Relatório Arqueológico. Arqueologia Preventiva na Área Diretamente Afetada pela Duplicação da Rodovia BR-230 - Marabá, Pará. 2011. Fundação Casa da Cultura de Marabá. Marabá, Pará. 2011.

MERLIM, A. O. Macrofauna edáfica em ecossistemas preservados e degradados de Araucária no Parque Estadual de Campos do Jordão, SP. 2005. 103 f. Tese (Mestrado em Ecologia de Agroecossistemas). Escola Superior de Agricultura Luiz de Queiroz, Universidade de São Paulo. Piracicaba, SP. 2005.

MOÇO, M. K. S. Fauna do solo em diferentes agrossistemas de cacau no sul da Bahia. 2006. 96 f. Tese (Mestrado em Produção Vegetal). Universidade Estadual do Norte Fluminense Darcy Ribeiro. Campos dos Goytacazes (RJ). 2006.

NEVES JUNIOR, A. F. Qualidade física de solos com horizonte antrópico (Terra Preta de Índio) na Amazônia Central. 2008. Tese (Doutorado em Solos e Nutrição de Plantas) - Escola Superior de Agricultura Luiz de Queiroz, Universidade de São Paulo, Piracicaba, 2008.

NBR 18. Condições e meio ambiente de trabalho na indústria da construção. Disponível em: < http://portal.mte.gov.br/data/files/8A7C812D3DCADFC3013F7C5680504D06/NR18\%20(atualizada\%202013)\%20-\%20sem\%2024\%20meses.pdf >. Acesso em: 21 jul. 2013.

OLIVEIRA, M. L. S. Indicadores da qualidade de solos sob diferentes sistemas de cultivo com as espécies de Paricá (Schizolobium amazonicum var. amazonicum HUBER ex DUCKE) e Curauá (Ananas comosus var. erectifoliius [L. B. SMITH] COPPENS \& LEAL) no município de Aurora do Pará (PA). 2009. Tese (Doutorado em Agronomia). Universidade Federal Rural da Amazônia, 2009.

OLIVEIRA, T. C. Avaliação de índices de qualidade física do solo e predição de parâmetros multifractais de solos sob Floresta Estacional Semidecidual. 2013. Dissertação (Mestrado em 
Solos e Nutrição de Plantas) - Escola Superior de Agricultura Luiz de Queiroz, Universidade de São Paulo, Piracicaba, 2013.

PARÁ (Estado). Secretaria de Estado de Planejamento, Orçamento e Finanças. Estatística Municipal: Marabá, Pará. 2013. Disponível em:< http://www.idesp.pa.gov.br/paginas/produtos/EstatisticaMunicipal/pdf/Maraba.pdf >. Acesso em: 9 jun. 2013.

PEIXOTO, M. F. S. P. Atributos físicos, químicos e biológicos como indicadores da qualidade do solo. 2008. Notas de aula. Universidade Federal do Recôncavo da Bahia. 2008.

PEREIRA JÚNIOR, A. Fertilidade e fauna edáfica em solo sob reflorestamento com Paricá (Schizolobium amazonicum Huber ex Ducke) no município de Aurora do Pará. 2011. Dissertação (Mestrado em Ciências Ambientais). Universidade Federal do Pará, Belém, 2011.

PEREIRA, W. L. M. et al. Propriedades químicas de um Latossolo amarelo cultivado com pastagens na Amazônia Oriental. Scientia Agricola, v.57, n.3, p.531 - 537, 2000.

RAIOL, J. A. (coord.). Perspectivas para o meio ambiente urbano: GEO Marabá. 2010. Belém, Pará. 2010. Disponível em: 〈http://www.pnuma.org.br/admin/publicacoes/texto/geo_maraba.pdf〉. Acesso em: 09 jun. 2013.

RIBEIRO, L. Era uma vez uma vila. REVISTA FOCO CARAJÁS. Edição no 4 marços/abril 2009a. Disponível em: <http://www.fococarajas.com.br/index.php/rev-online2/category/index.php?option=com_flippingbook\&view=book\&id=8:edicao42009\&catid=4:ano200 9\&tmpl=component>. Acesso em: 17 jul. 2013.

RIBEIRO, L. Vila Socó: Moradores querem uma nova casa e mais R\$ 10 mil de indenização para poder deixar a área ocupada. 2009b. JORNAL OPINIÃO. Marabá, Pará. 2009.

REIS, J. T. Política Nacional de Resíduos Sólidos. In: Âmbito Jurídico, Rio Grande, XIV, n. 87, abr 2011. Disponível em: <http://www.ambitojuridico.com.br/site/index.php?n_link=revista_artigos_leitura\&artigo_id=9150>.Acesso em: 21 out. 2013.

ROCHA, F. M. Legislação e controle ambiental. 2007. The Agro-Energy Expansion and its impacto $n$ the Brazilian Ecosystems. Rio de Janeiro, RJ. 2007. Disponível em: <http://www.conservation.org.br/publicacoes/files/5_Flavio_Montiel_Rocha_IBAMA.pdf >. Acesso em: 21 out. 2013.

ROUSSELET, E. S. Manual de procedimentos para implantação e funcionamento de canteiro de obras na indústria da construção. S/d. Sociedade Brasileira de Engenharia de Segurança SOBES. Disponível em: <http://sobes.org.br/site/wp-content/uploads/2009/08/canteiro.pdf>. Acesso em: 21 Jul, 2013.

RUIVO, M. L. P. et al. LBA - Esecaflor artificially induced drought in Caxiuanã Reserve, East Amazonia: soil properties and litter spider fauna. Earth Interactions, v.11, n.8, p.1 - 13, 2007.

SÁNCHEZ, G. A. R. Variabilidade espacial do carbono e outros atributos do solo em uma párea destinada ao reflorestamento no Rio Grande do Norte. 2010. Dissertação (Mestrado em Ciências) Escola Superior de Agricultura, Universidade de São Paulo. Piracicaba, 2010. 
SANEPAR. Canteiro de obras - Especificações. 2012. Manual de obras e saneamento. 4 ed. Módulo 01. Disponível em: < http://site.sanepar.com.br/sites/site.sanepar.com.br/files/informacoestecnicas/mos-4a-edicao/modulo_1_4ed_v00_-_canteiro_de_obras.pdf >. Acesso em: 21 Jul, 2013.

SANTANA, D. P.; BAHIA FILHO, A. F. C. Indicadores de qualidade de solo. 1999. Empresa Brasileira de Pesquisa de Pesquisa Agropecuária Milho e Sorgo. Disponível em: <http://www.alice.cnptia.embrapa.br/bitstream/doc/482765/1/Indicadoresqualidade.pdf>. Acesso em: 21 out. 2013.

SANTOS, N. Vila Socó: Remanescentes querem a criação de um Parque Ambiental. 2009. JORNAL OPINIÃO. Marabá, Pará. 2009.

SILVA, S. B. Análise de solos. 2003. Universidade Federal Rural da Amazônia. Belém, Pará. 2003.

SILVA, G. R.; SILVA JÚNIOR., M. L.; MELO, V. S. Efeitos de diferentes usos da terra sobre as características químicas de um latossolo amarelo do estado do Pará. Acta Amazonica. v. 36, n. 2. Manaus. 2006.

SILVA, R. F. et al. Macrofauna invertebrada do solo em sistema integrado de produção agropecuária no Cerrado. Acta Sci., Agron. Maringá, v. 30, n. 4. 2008.

SIQUEIRA, J. O. et al. Matéria orgânica em solos de áreas degradas. In: SANTOS, G. A. et al. (Ed.). Fundamentos da Matéria Orgânica do sol: ecossistemas tropicais e subtropicais. $2^{\mathrm{a}}$ ed. Porto Alegre: Metrópole. 2008. p. 495-524.

SOUSA, E. Vila Socó: Ainda não está definido exatamente para onde os habitantes da área serão remanejados e assim, moradores têm futuro incerto. 2009. JORNAL OPINIÃO. Marabá, Pará. 2009.

SOUSA, S. Vila Socó: Comunidade vive esquecida em meio à civilização. 2009. JORNAL OPINIÃO. Marabá, Pará. 2009.

SOUZA, M. I. L. et al. Características físicas, químicas, conteúdo de água em solos convertidos de savanas para plantio de Acacia mangium. Revista Agroambiente online. v.4 n.1, p.20 - 26, 2010.

SUNG, C. T. B. Software TAL 4.2. (1996-2002). Dept. Land Management, Universiti Putra Malaysia. Disponível em: <www.agri.upm.edu.my/^chris/tal>. Acesso em: 24 out. 2013.

TONGNON, A. A.; DEMATTÊ, J. L. I.; DEMATTÊ, J. A. M. Teor e distribuição da matéria orgânica em latossolos das regiões da floresta Amazônica e dos Cerrados do Brasil central. Scientia Agricola. v. 55. N. 3 Piracicaba, SP. 2002.

VEZZANI, F. M. et al. Matéria orgânica e qualidade do solo. In: SANTOS, G. A. et al. (Ed.). Fundamentos da Matéria Orgânica do sol: ecossistemas tropicais e subtropicais. $2^{\mathrm{a}}$ ed. Porto Alegre: Metrópole. 2008. p. 483-494.

VEZZANI, F. M.; MIELNICZUK, J. Uma visão sobre qualidade do solo. Revista Brasileira de Ciência do Solo. Viçosa, v. 33. n. 4. 2009.

VICENTE, N. M. F. et al. Fauna Edáfica Auxiliando a Recuperação de Áreas Degradadas do Córrego Brejaúba, MG. 2010. Floresta e Ambiente 2010; v. 17. p. 110. 
Milena Cristina Dias Barros

Engenheira Ambiental.

milenacdias@hotmail.com

Antônio Pereira Júnior

Mestre em Ciências Ambentais

Universidade do Estado do Pará.

Departamento de Engenharia Ambiental.

antonio.junior@uepa.br 